\title{
URANIUM AND THORIUM DECAY SERIES ISOTOPIC CONSTRAINTS ON THE SOURCE AND RESIDENCE TIME OF SOLUTES IN THE YELLOWSTONE HYDROTHERMAL SYSTEM
}

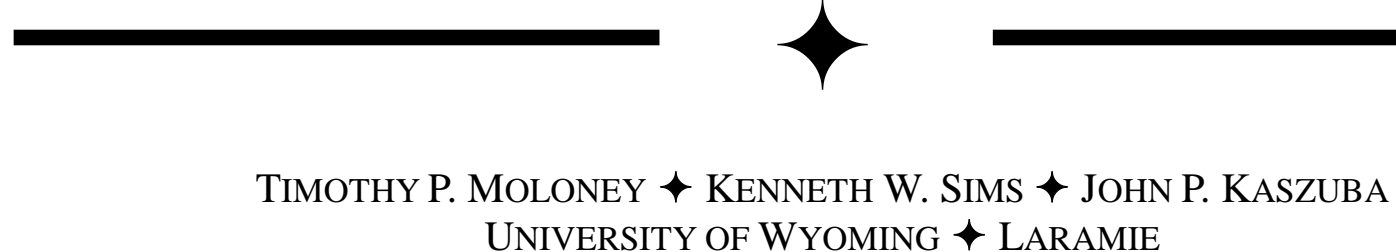
UNIVERSITY OF WYOMING $\uparrow$ LARAMIE

\begin{abstract}
$\downarrow \quad$ Abstract
Hydrothermal fluids in Yellowstone National Park have widely varying chemical composition. Heat and volatile flux from the hydrothermal system can be estimated by monitoring the composition and volume of emitted hydrothermal fluid, but the source of solutes in hydrothermal fluid is often nebulous and the geochemical processes that affect the nuclides are poorly understood.
\end{abstract}

Measurements of ${ }^{220} \mathrm{Rn}$ and ${ }^{222} \mathrm{Rn}$ activity in hydrothermal fluids and of $\mathrm{CO}_{2}$ flux from fumaroles and hot springs were carried out in Yellowstone National Park during the summer of 2010. We observed a weak relationship between $\left({ }^{220} \mathrm{Rn} /{ }^{222} \mathrm{Rn}\right)$ and $\mathrm{CO}_{2}$ flux, which indicates that $\mathrm{CO}_{2}$ acts as a carrier gas to bring radon to the surface, but the radon is sourced from aquifer rocks rather than magma. If radon reaching the surface were sourced from magma below Yellowstone, there would be a stronger correlation between $\left({ }^{220} \mathrm{Rn} /{ }^{222} \mathrm{Rn}\right)$ and $\mathrm{CO}_{2}$ flux.

Measurements of ${ }^{223} \mathrm{Ra},{ }^{224} \mathrm{Ra},{ }^{226} \mathrm{Ra},{ }^{228} \mathrm{Ra}$, and major solute chemistry in hot spring waters support the hypothesis that the time scale of solute transport from the deep hydrothermal reservoir is long compared to the half lives of ${ }^{220} \mathrm{Rn}$ and ${ }^{222} \mathrm{Rn}$, which are useful for processes operating on the time scale of 5 minutes to 20 days. Radium isotope activities in hot springs indicate that the solute transport time varies significantly from region to region, indicating that circulation in some areas operates on the time scale of ${ }^{224} \mathrm{Ra} /{ }^{223} \mathrm{Ra}(20-55$ days) and circulation in other areas operates on the time scale of ${ }^{228} \mathrm{Ra} /{ }^{226} \mathrm{Ra}$ (25-1600 years). The radium isotope composition of hot spring water is also

influenced by differences in regional aquifer rocks and geochemical processes such as sorption and mineral precipitation. In summary, geochemical and hydrothermal processes in Yellowstone operate on many different time scales and in diverse geologic conditions, but radionuclide activities possess excellent potential to study these complex phenomena.

\section{$\uparrow \quad$ INTRODUCTION}

Geothermal monitoring in Yellowstone National Park (YNP) is important for volcanic hazard assessment and forecasting of potential activity. Yet fundamental questions regarding the source of nuclides in geothermal waters and the time scale of water-rock interaction in the Yellowstone hydrothermal system remain unresolved. Lacking information on the time scale of subsurface hydrothermal fluid circulation, there exists an indeterminate lag time between observed changes in the geochemistry or activity of hydrothermal features at the surface and changes in hydrothermal and volcanic processes at depth. Additionally, the chemistry of the Yellowstone system can serve as a rough natural analogue for mid-ocean ridge hydrothermal systems where direct geochemical sampling from would be difficult or cost prohibitive. Understanding hydrothermal processes in Yellowstone is important because hydrothermal 
processes are associated worldwide with epithermal ore deposits of gold, copper, lead, zinc, and other economically valuable minerals.

To constrain the time scale of processes in the active and dynamic Yellowstone hydrothermal system requires the use of chronometers capable of measuring current to recent processes. One such chronometer is the uranium-thorium series of radioisotopes (Figure 1). Radon and radium isotopes are particularly well suited to the study of current to recent processes in Yellowstone, because of the wide range in the time scale of their half-lives and their different behavior in solution.

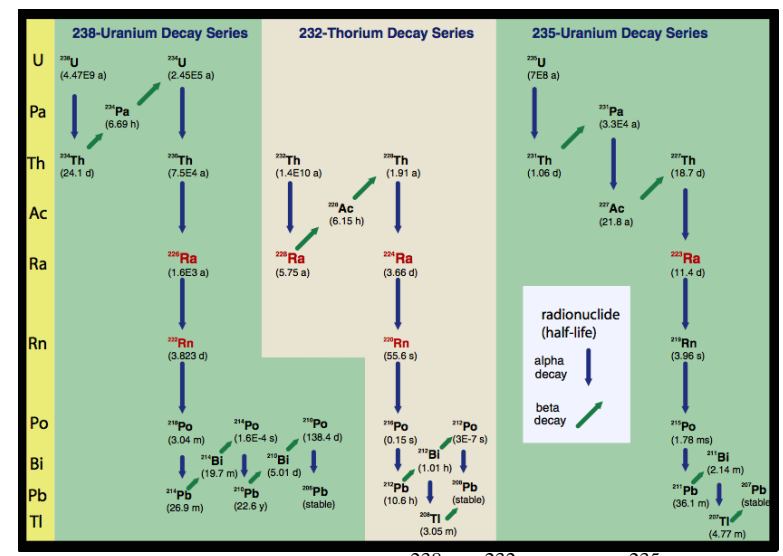

Figure 1. The decay series of ${ }^{238} \mathrm{U},{ }^{232} \mathrm{Th}$, and ${ }^{235} \mathrm{U}$. The half-life of each isotope is given under the symbol. Isotopes measured in this study are shown in red.

Studies of radium isotopes in YNP have previously explored regional differences in hydrothermal geochemistry (Clark and Turekian, 1990; Sturchio et al., 1993), the time scale of waterrock interactions in thermal aquifers (Clark and Turekian, 1990), the aquifer properties controlling isotopic composition and ratios (Sturchio et al., 1989; Sturchio et al., 1993), and near surface groundwater flow velocities (Sturchio et al., 1993). Some reconnaissance data on radon in thermal areas has been collected (Jaworowski et al. 1996). However, to date the spatial and temporal distribution of ${ }^{222} \mathrm{Rn}$ in areas of thermal activity has not been studied in detail. Neither has any study of its sister isotope ${ }^{220} \mathrm{Rn}$ (thoron) been carried out.

The purpose of this study is to measure radon, radium, chloride, and $\mathrm{CO}_{2}$ in water samples from hot springs and in soil gas. The isotopic ratios of radon and radium will be used in conjunction with measurements of magmatic volatiles (chlorine and $\mathrm{CO}_{2}$ ) to estimate the relative contribution of the magmatic source vs. non-magmatic sources, i.e., soil and aquifer rocks. The measured activities of radium and radon, based on their half-lives, will be used to assess relative time scales of hydrothermal circulation in different areas.

\section{STUDY AREA}

The Yellowstone Plateau volcanic field is the world's largest and most concentrated area of continental hydrothermal activity (Figure 2). Over the past 2.2 million years, the region has experienced three explosive caldera forming eruptions, the most recent of which expelled $>1000 \mathrm{~km}^{3}$ of rhyolitic magma about 640,000 years ago (Christiansen, 2001). Two active resurgent domes exist inside the caldera boundary. Heat flux from the magma system below this still active volcanic field is maintained by the circulation of hydrothermal fluid overlying the magma chamber. Heat and volatile flux from the hydrothermal system can be estimated by monitoring the composition and volume of emitted hydrothermal fluid.

There are three principal types of hydrothermal fluid in Yellowstone, classified according to their $\mathrm{pH}$ and major anion composition: neutral-chloride, acid-sulfate, and calciumbicarbonate sulfate (Fournier, 1989). Neutralchloride fluids generally surface at lower elevations (Lowenstern and Hurwitz, 2008), and they are commonly associated with areas of major geyser activity (e.g., Old Faithful). Neutral chloride fluids contain high concentrations of chloride, alkalis, and silica, but low concentrations of sulfate and alkaline earths. Acid-sulfate fluids generally surface at higher elevations, and are commonly associated with mudpots and fumarolic activity. These fluids form when geothermal steam (containing $\mathrm{H}_{2} \mathrm{~S}$ ) condenses into shallow, oxygenated meteoric water. The $\mathrm{H}_{2} \mathrm{~S}$ is oxidized to sulfate, lowering the $\mathrm{pH}$ of the solution and producing a sulfate-rich fluid. Calciumbicarbonate-sulfate type waters have high concentrations of $\mathrm{Ca}^{2+}, \mathrm{HCO}_{3}{ }^{-}$, and $\mathrm{SO}_{4}{ }^{2-}$. These waters generally have high TDS compared to other Yellowstone waters. They are generated by dissolution of sedimentary rocks (notably limestone and $\mathrm{CaSO}_{4}$ minerals) at depth, typically at lower temperatures compared with other hydrothermal fluids in Yellowstone. Calcium-bicarbonate-sulfate waters precipitate travertine at the surface. Such waters may occur in many areas in Yellowstone, but they are most common in the area of Mammoth Hot Springs.

Surficial hydrothermal discharge in Yellowstone occurs primarily from areas within or around the 640,000 year old caldera. There is a 
major area of activity in the valley of the Firehole River, including the Upper, Lower, Midway, and Lone Star Geyser Basins. The Firehole River carves its path between rhyolite lava flows and also lies near the ring-fracture zone of a resurgent dome. Another major area of activity is Norris Geyser Basin, which lies just outside the caldera rim at the intersection of two fault zones. A concentration of earthquake activity extends west from Norris to Hebgen Lake (site of a 7.5 magnitude earthquake in 1959), and an alignment of normal faults and fractures termed the Norris-Mammoth Corridor extends north from Norris to Mammoth Hot Springs. The Norris-Mammoth Corridor is also a locus of hydrothermal activity.

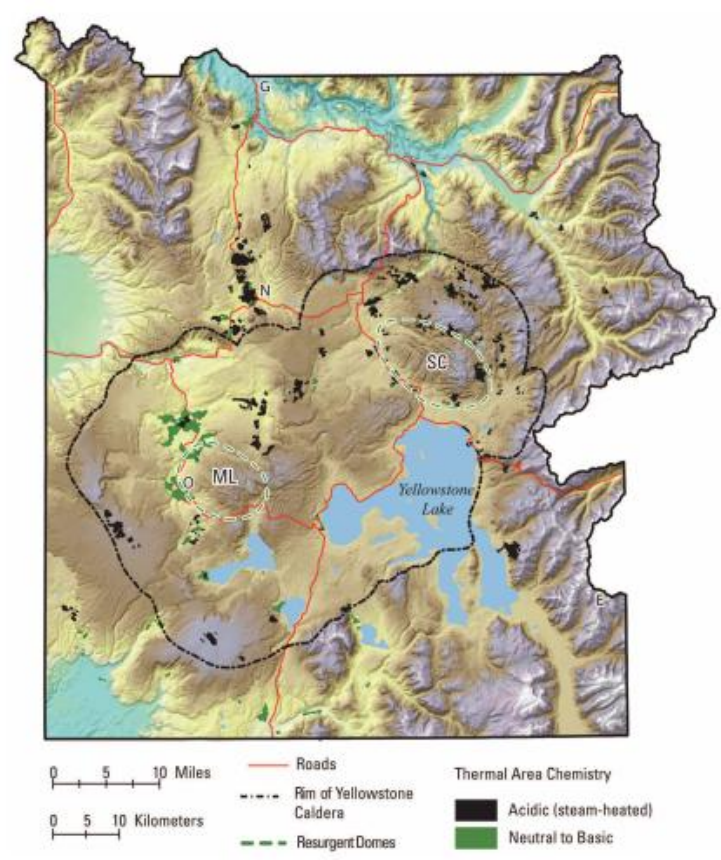

Figure 2. Yellowstone National Park's surficial geography and major areas of hydrothermal activity. Modified from Lowenstern and Hurwitz (2008).

Radiogenic nuclides in Yellowstone's hydrothermal fluids may be sourced from decay of uranium and thorium in magma, aquifer rocks, or soils. Secular equilibrium is likely to exist in the magma reservoir between ${ }^{238} \mathrm{U}$ and ${ }^{226} \mathrm{Ra}$, and between ${ }^{232} \mathrm{Th}$ and ${ }^{224} \mathrm{Ra}$. U, Th, Ra, and/or $\mathrm{Rn}$ escape from the magma dissolved in gases and brines, and proceed to interact with aquifer rocks on the way to the surface. Quaternary volcanic rocks overlying the magma chamber range from $\sim 600,000$ to $\sim 70,000$ years in age and commonly display disequilibrium in the upper portion of the $\mathrm{U}$ and $\mathrm{Th}$ decay chains (Vasquez and Reid, 2002). Mesozoic sedimentary rocks are the principle aquifers north of the caldera. These rocks generally contain little ${ }^{232} \mathrm{Th}$
(Clark and Turekian, 1990; Sturchio et al., 1993). On the east side of Yellowstone, the rocks of the $\sim 50 \mathrm{Ma}$ Absaroka Volcanic Supergroup are present.

The locations sampled in this study were thermal springs (Appendix Table 1), rivers (Appendix Table 2), fumaroles (Appendix Table 3), and areas of bedrock exposure for collection of rock samples (Appendix Table 4). Sites were selected based on three criteria: 1) Water-chemistry type and geographic location. Sites were selected to represent neutral-chloride, acid-sulfate, and calciumbicarbonate-sulfate water types, and to provide comparison between different major thermal areas; (2) Ease of access. Sample sites needed to be accessible by a day hike, but remote enough to avoid crowds of park visitors; (3) anticipated geochemistry. An effort was made to sample some springs for which previous data on radionuclides exists. Water samples were collected and gas measurements made in the field between May $24^{\text {th }}, 2010$ and September $24^{\text {th }}, 2010$.

Measurements of $\mathrm{CO}_{2}$ efflux and radon activity in gas were made at each locality. Some springs were sampled several times to determine the seasonal variability in radionuclide activity. In total, 25 gas measurements were taken, and 23 springs were sampled. Due to equipment failure or other logistical difficulty, it was not always possible to measure all parameters at each site.

\section{$\uparrow \quad$ METHODS}

\section{Radon}

Radon-222 and ${ }^{220} \mathrm{Rn}$ were measured in the field with the Durridge RAD7, RAD AQUA, and RAD $\mathrm{H}_{2} \mathrm{O}$ (http://www.durridge.com). The instruments were calibrated by Durridge prior to the field season. The RAD7 is a portable, battery powered radon-in-air monitor, which uses a solidstate alpha detector to convert alpha radiation to an electrical signal. Based on the energy of the signal, the detector discriminates between the decays of the different daughter products. The $\mathrm{RAD} \mathrm{H}_{2} \mathrm{O}$ is an attachment that bubbles gas through a small sample of water and intakes the gas into the RAD7 for detection of radon. Because of the time delay in collecting a sample and setting up the sampling apparatus, it is usually impossible to measure ${ }^{220} \mathrm{Rn}$ with the RAD $\mathrm{H}_{2} \mathrm{O}$. The RAD AQUA is a continuous radon-in-water monitor. Water passes continuously through the exchanger in the RAD AQUA, and air flows in a closed loop through the exchanger and through the RAD7. This allows radon in water to 
come into equilibrium with the radon in the air, and the RAD AQUA (detection limit below $1 \mathrm{pCi} / \mathrm{L}$ ), but the $\mathrm{RAD} \mathrm{H}_{2} \mathrm{O}$ requires only a $250 \mathrm{~mL}$ water sample, whereas the RAD AQUA requires continuous flow. The most appropriate method for analysis of radon and thoron in water was chosen on a site-to-site basis. Generally, the RAD AQUA was used if possible, due to its lower detection limit, higher degree of accuracy, and its ability to detect ${ }^{220} \mathrm{Rn}$.

\section{Radium}

Radium activities in water were measured following the method of Moore and Arnold (1996) and Moore (2008). Radium-228, ${ }^{226} \mathrm{Ra},{ }^{224} \mathrm{Ra}$, and ${ }^{223} \mathrm{Ra}$ were pre-concentrated on manganese fibers in the field. Ten to $21 \mathrm{~L}$ of water were pumped from the source through a plastic column filled with acrylic fibers impregnated with manganese oxide. The water was collected in a reservoir so a volume measurement could be made, and then returned to the channel. The activity of ${ }^{223} \mathrm{Ra}$ and ${ }^{224} \mathrm{Ra}$ on the $\mathrm{Mn}$ fibers was measured within 3 days in a field laboratory with a radium delayed coincidence counter (or $\mathrm{RaDeCC}^{\mathrm{TM}}$ ). The RaDeCC is a large Lucas Cell, which uses a pump and helium carrier gas to distribute built-up ${ }^{220} \mathrm{Rn}$ and ${ }^{219} \mathrm{Rn}$ throughout an air loop. The loop is sealed for 5 minutes to allow daughter ingrowth, and counted for approximately three hours with delayed coincidence counting software. The system was calibrated with a standard solution of ${ }^{228} \mathrm{Ra}$. The RaDeCC method has very low error $( \pm 10 \%)$, and an analytical detection limit of approximately $0.0005 \mathrm{dpm} / \mathrm{L}$ (Moore, 2008).

The activity of ${ }^{228} \mathrm{Ra}$ on the Mn fibers was determined subsequently by repeated counts on the $\mathrm{RaDeCC}$ to monitor the ingrowth curve of its greatgranddaughter, ${ }^{224} \mathrm{Ra}$. Radium-224 quickly establishes secular equilibrium with its parent ${ }^{228} \mathrm{Th}$, which is in transient equilibrium with ${ }^{228} \mathrm{Ra}$. The Bateman Equation is fit to the data and used to extrapolate to the initial activity of ${ }^{228} \mathrm{Ra}$ (Figure 3). For this analysis, each Mn fiber sample was counted at least 3 times over a period of approximately 6 six months. For comparison, six selected samples were shipped to Woods Hole Oceanographic Institution where the activity of ${ }^{228} \mathrm{Ra}$ was also determined by gamma counting of its direct daughter, ${ }^{228} \mathrm{Ac}$.

The activity of ${ }^{226} \mathrm{Ra}$ on the Mn fibers was measured by counting with a RAD7 (Kim et al., 2001; Dimova et al., 2007). The Mn fibers were sealed in a column for $\geq 20$ days to allow ingrowth of ${ }^{222} \mathrm{Rn}$, and the column was then attached to a recirculating closed-air loop connected to the RAD7.
Each sample was counted for at least 3 hours, and only the last 2 hours of counting data was used to calculate ${ }^{226}$ Ra activity. The RAD7 counts the decays of ${ }^{218} \mathrm{Po}$, the direct daughter of ${ }^{222} \mathrm{Rn}$, which establishes secular equilibrium with ${ }^{222} \mathrm{Rn}$ after about 15 minutes. The RAD7 was calibrated with a ${ }^{226} \mathrm{Ra}$ standard solution.

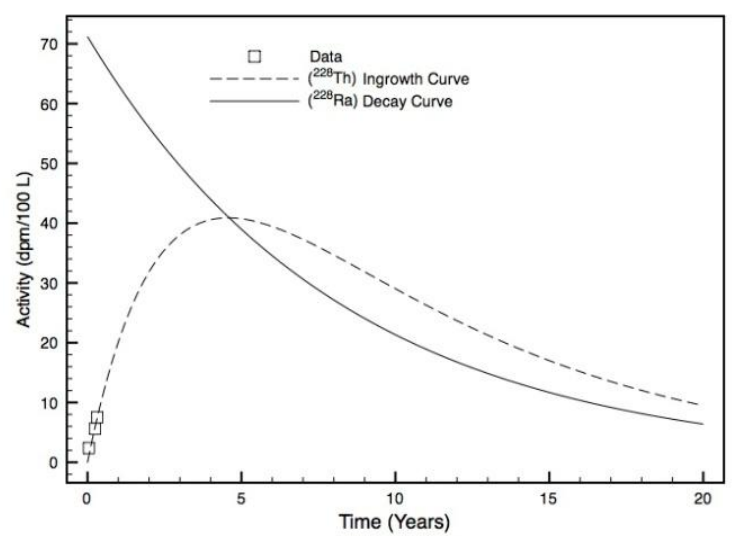

Figure 3. Example of ${ }^{228} \mathrm{Th}$ ingrowth data obtained by measuring ${ }^{224} \mathrm{Ra}$ on the RaDeCC, and the equations fit to estimate the initial activity of ${ }^{228} \mathrm{Ra}$. Data shown is for the sample from Beryl Spring on 9/22/2010.

\section{$\mathrm{CO}_{2}$ Flux Measurements}

Carbon dioxide effluxes in soil and fumarole emissions were measured using the accumulation chamber method (Chiodini et al., 1998). A cylindrical chamber with an open bottom was placed on the ground surface and the rate of increase in the $\mathrm{CO}_{2}$ concentration inside the chamber is measured. The chamber mixes the gas with an internal fan and is connected with a portable non-dispersive infrared spectrophotometer. The change in concentration over the time of the measurement is proportional to the $\mathrm{CO}_{2}$ efflux.

$\mathrm{CO}_{2}$ flux from the surface of hot springs was measured by a modified version of the accumulation chamber method. In this case the cylindrical chamber was a 1-liter HDPE bottle attached to an extension pole used to place the bottle near the center of the spring while the operator controlled it safely from the edge. An outlet tube at the top of the bottle was connected to the portable detector, while a return tube was run from the detector outlet to the side of the bottle near the base (just above the water surface when sampling). This system suffers from the drawback that there is no internal fan to ensure mixing, but the placement of the outlet and return tubes on the bottle attempts to promote the most mixing possible. 


\section{Other Geochemical Parameters}

On-site geochemical and environmental parameters were measured with a YSI Professional Plus multi-meter (http://www.ysi.com/). The multimeter was configured to measure pressure, temperature, dissolved oxygen, $\mathrm{pH}$, oxidationreduction potential, and specific conductance. The meter was calibrated prior the start of fieldwork and approximately every two weeks throughout the field season.

From each spring sampled, two 50-mL water samples were collected for chemical analysis. The water was collected from its source with a $60-\mathrm{mL}$ HDPE syringe and filtered through a $0.45-\mu \mathrm{m}$ syringe filter into $60-\mathrm{mL}$ LDPE bottles. One sample was acidified with $1 \% \mathrm{v} / \mathrm{v}$ of ultra-high purity nitric acid for analysis of cations. No chemical preservative was added to the second sample, which was used to determine anion concentrations. The samples were stored on ice or in a refrigerator and were analyzed at the US Geological Survey trace metal laboratory in Boulder, Colorado. Concentrations of $\mathrm{Br}, \mathrm{Cl}, \mathrm{F}$, and $\mathrm{SO}_{4}$ were measured by ion chromatography and cations were measured by inductively coupled plasma-optical emission spectrometry using the methods described in Ball et al. (2010). Alkalinity was determined by titration with $\mathrm{H}_{2} \mathrm{SO}_{4}$ to the $\mathrm{HCO}_{3}$ endpoint (Barringer and Johnsson, 1996). In the case where our research group was collaborating in the field with the USGS-Boulder research group and sampling the same springs, we used their chemical data. The methods used by the by the USGS-Boulder group are detailed in Ball et al. (2010).

Data on helium isotopes in gas emissions was provided by Jacob Lowenstern (Bergfeld et al, in press). In some cases, radionuclide activities measured at several discrete locations were averaged together to give a single value for comparison to the helium isotope data set.

\section{$\downarrow \quad$ PRELIMINARY RESUltS}

\section{Spring Chemistry}

Geochemical and environmental parameters measured on-site are summarized in Appendix Table 5. Basic water chemistry of thermal springs determined by laboratory analysis is summarized in Appendix Table 6. Charge balances were calculated using WATEQ4F by the USGS trace metal lab in Boulder, CO. Charge was balanced within $+/-5 \%$ for all samples except Soda Butte $5 / 30$ and Narrow Gauge Terrace 9/24, where anion charge appeared anomalously low. The $\mathrm{pH}$ of the sampled springs ranged from 2.36 to 9.28 . Chloride ranged from 55 to $792 \mathrm{mg} / \mathrm{L},\left[\mathrm{SO}_{4}{ }^{2-}\right]$ ranged from 15 to $607 \mathrm{mg} / \mathrm{L}$, $\left({ }^{223} \mathrm{Ra}\right)$ ranged from 0.0001 to $3.13 \mathrm{dpm} / \mathrm{L},\left({ }^{224} \mathrm{Ra}\right)$ ranged from 0.0053 to $21.47 \mathrm{dpm} / \mathrm{L},\left({ }^{226} \mathrm{Ra}\right)$ ranged from 0.037 to $1.39 \mathrm{dpm} / \mathrm{L}$, and $\left({ }^{228} \mathrm{Ra}\right)$ ranged from 0.05 to $20.9 \mathrm{dpm} / \mathrm{L}$.

The springs sampled divide into three major groups based on location and water-type. Springs from Norris Geyser Basin and nearby Beryl Spring have highly variable $\mathrm{pH}$ and chloride concentration but are generally high in sulfate and low in fluoride. Generally these springs are best classified as acidsulfate water type. Springs from the Lower Geyser Basin and nearby Rabbit Creek Hot Springs can be classified as neutral-chloride type waters. They are generally alkaline, high in chloride and fluoride, and low in sulfate. The springs from Mammoth Hot Springs are calcium-bicarbonate-sulfate water type. They are neutral to alkaline with high concentrations of sulfate, bicarbonate, and alkali earths.

The most significant correlations in the chemistry of spring water were between radium and $\mathrm{pH}$ (Spearman's Correlation, $\rho=-0.609$ (21), $p$ (twotailed) <.01), radium and ORP (Spearman's Correlation, $\rho=0.712(21), p$ (two-tailed) <.01), radium and DO (Spearman's Correlation, $\rho=$ $0.714(13), p$ (two-tailed) <.01), radium and barium (Spearman's Correlation, $\rho=0.621(21), p$ (twotailed) <.01), and radium and calcium (Spearman's Correlation, $\rho=0.849(21), p$ (two-tailed) <.01). Important observations included that radium activity in springs was positively correlated with many major dissolved ions including $\mathrm{Br}, \mathrm{SO}_{4}, \mathrm{Cl}, \mathrm{B}, \mathrm{Ba}, \mathrm{Ca}, \mathrm{Fe}$, $\mathrm{K}, \mathrm{Li}, \mathrm{Mg}, \mathrm{Mn}, \mathrm{Mo}$, and $\mathrm{Sr}$, and was also controlled by the Eh and $\mathrm{pH}$ of the spring water.

\section{Radon}

Measurements of radon isotopes in gas emissions from fumaroles and $\mathrm{CO}_{2}$ fluxes determined by the accumulation chamber method are given in Appendix Table 7. Radon activities measured in thermal springs are given in Appendix Table 8. Relevant activity ratios and $\mathrm{CO}_{2}$ fluxes determined by the modified accumulation chamber method are listed in Appendix Table 9. Combining all gas and water measurements, radon activities ranged from 0.1 to $1173 \mathrm{pCi} / \mathrm{L}$, thoron activities ranged from 0.2 to $300 \mathrm{pCi} / \mathrm{L}$, and $\mathrm{CO}_{2}$ fluxes ranged from 1.92 to 3909 $\mathrm{g} \mathrm{m}^{-2} \mathrm{~d}^{-1}$.

Radon activity in spring water showed a weak inverse relationship with spring temperature (not statistically significant). Radon activity was 
positively correlated with $\mathrm{CO}_{2}$ flux, Figure $4 \mathrm{~F}$, Spearman's Correlation, $\rho=0.364(42), p$ (two-tailed) $<.05)$, while Thoron activity increased with $\mathrm{CO}_{2}$ flux up to about $100 \mathrm{~g} \mathrm{~m}-2 \mathrm{~d}-1$ and decreased with increasing $\mathrm{CO}^{2}$ flux thereafter (Figure 4E). $\left({ }^{220} \mathrm{Rn} /{ }^{222} \mathrm{Rn}\right)$ and $\mathrm{CO}^{2}$ flux from springs and gas vents showed a weak inverse correlation (Figure 5, Spearman's Correlation, $\rho=-0.344[40], p$ [twotailed] <.05). In general, gas vents had higher $\left({ }^{220} \mathrm{Rn} /{ }^{222} \mathrm{Rn}\right.$ ) than springs (Figure $5 \mathrm{C}$ ). Mean $\left({ }^{220} \mathrm{Rn} /{ }^{222} \mathrm{Rn}\right)$ from gas vents was 2.4 , while mean $\left({ }^{220} \mathrm{Rn} /{ }^{222} \mathrm{Rn}\right)$ from springs was 0.69 .

In a limited dataset, neither radon, thoron, nor $\left({ }^{220} \mathrm{Rn} /{ }^{222} \mathrm{Rn}\right)$ showed any relationship with $\left({ }^{3} \mathrm{He} /{ }^{4} \mathrm{He}\right)$ values reported for thermal features by the USGS (Figure 6). Neither did thoron, radon, nor $\left({ }^{220} \mathrm{Rn} /{ }^{222} \mathrm{Rn}\right)$ show any relationship with chloride in spring water (Figure 7).
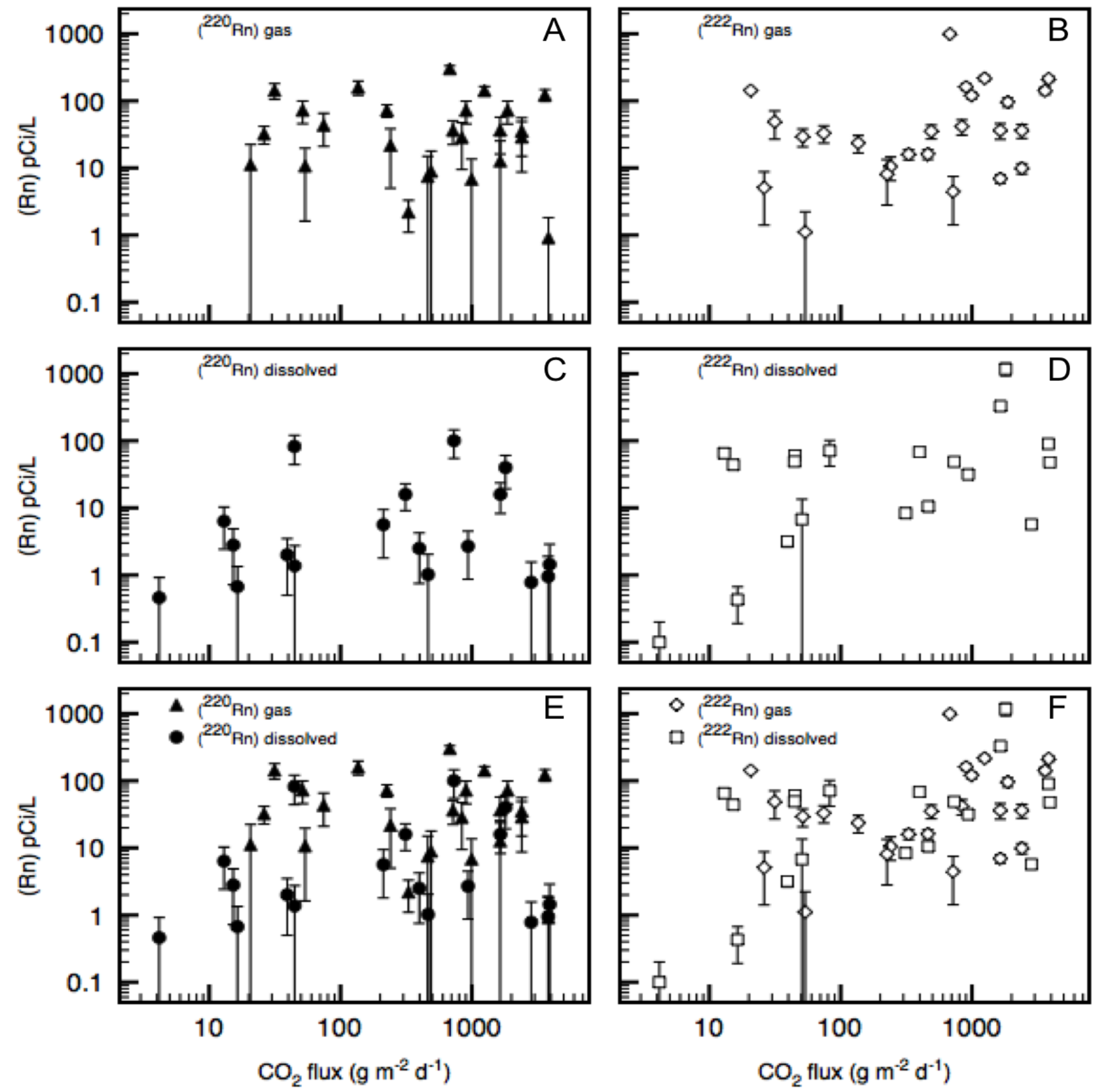

Figure 4. Data on ${ }^{222} \mathrm{Rn}$ and ${ }^{220} \mathrm{Rn}$ in hydrothermal fluids in Yellowstone. $\left({ }^{220} \mathrm{Rn}\right)$ appears to increase with $\mathrm{CO}_{2}$ flux to about 100 $\mathrm{g} \mathrm{m}^{-2} \mathrm{~d}^{-1}$, then decrease with higher $\mathrm{CO}_{2}$ fluxes $(\mathrm{E}) .\left({ }^{222} \mathrm{Rn}\right)$ shows a weak positive correlation for all values of $\mathrm{CO}_{2}$ flux $(\mathrm{F})$. 


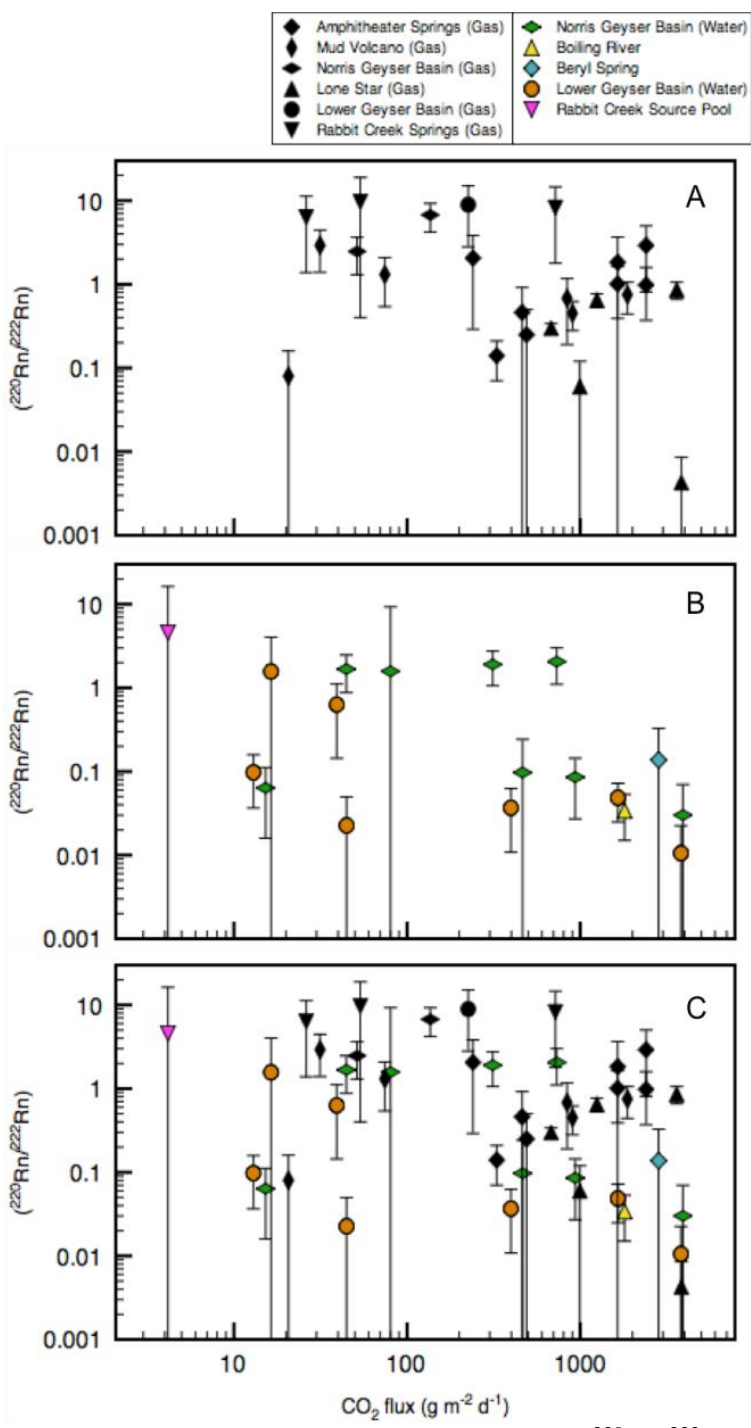

Figure 5. Weak inverse correlation between $\left({ }^{220} \mathrm{Rn} /{ }^{222} \mathrm{Rn}\right)$ and $\mathrm{CO}_{2}$ flux in from gas vents (A), thermal springs (B), as vents and springs $(\mathrm{C})$.

\section{Radium}

Radium activities measured in thermal springs are given in Appendix Table 8. Relevant activity ratios are listed in Appendix Table 9. Radium concentration in springs was positively correlated with many major dissolved ions including $\mathrm{Br}, \mathrm{SO}_{4}, \mathrm{Cl}, \mathrm{B}, \mathrm{Ba}, \mathrm{Ca}, \mathrm{Fe}, \mathrm{K}, \mathrm{Li}, \mathrm{Mg}, \mathrm{Mn}, \mathrm{Mo}$, and $\mathrm{Sr}$, and was also significantly correlated wtih the $\mathrm{Eh}$, Spearman's Correlation, $\rho=0.712(21), p$ (two-tailed) $<.01)$ and $\mathrm{pH}$, Spearman's Correlation, $\rho=$ $0.609(21), p$ (two-tailed) <.01) of the spring water. Radium activity was inversely correlated with fluoride concentration. ((Spearman's Correlation, $\rho=$ $-0.644(20), p$ (two-tailed) <.01)).
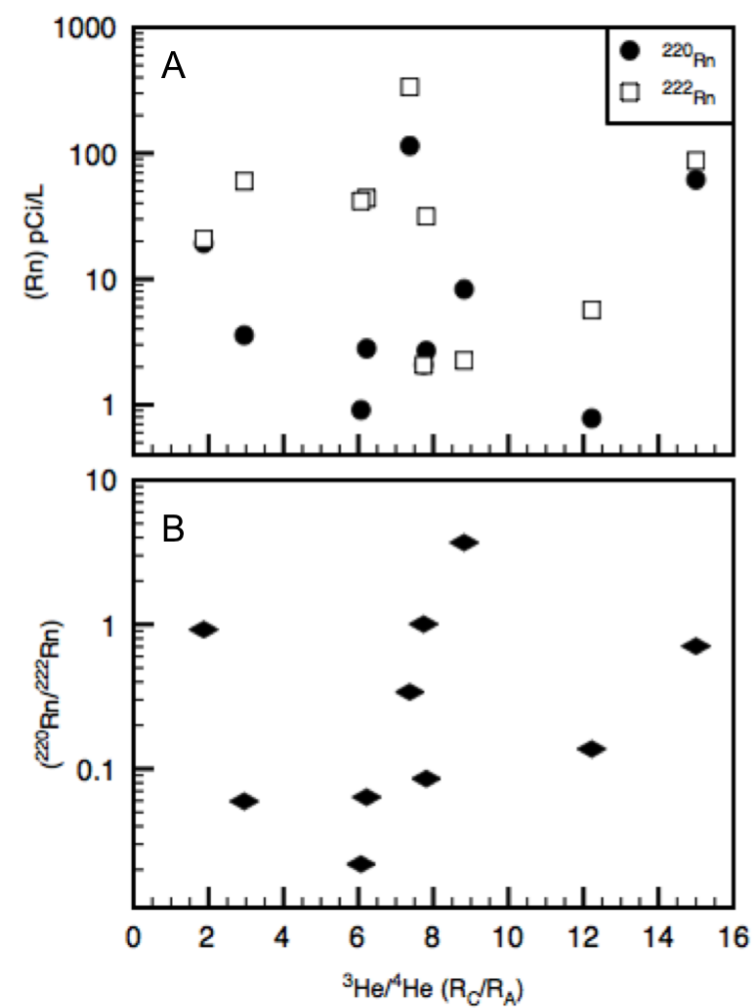

Figure 6. Radon isotopes show no relationship with helium isotope ratios in Yellowstone. Data on $\left({ }^{3} \mathrm{He} /{ }^{4} \mathrm{He}\right)$ from Bergfeld et al., in press. The measurements of radon and helium isotopes were not concurrent and in some cases represent an average of available data points in a similar area.

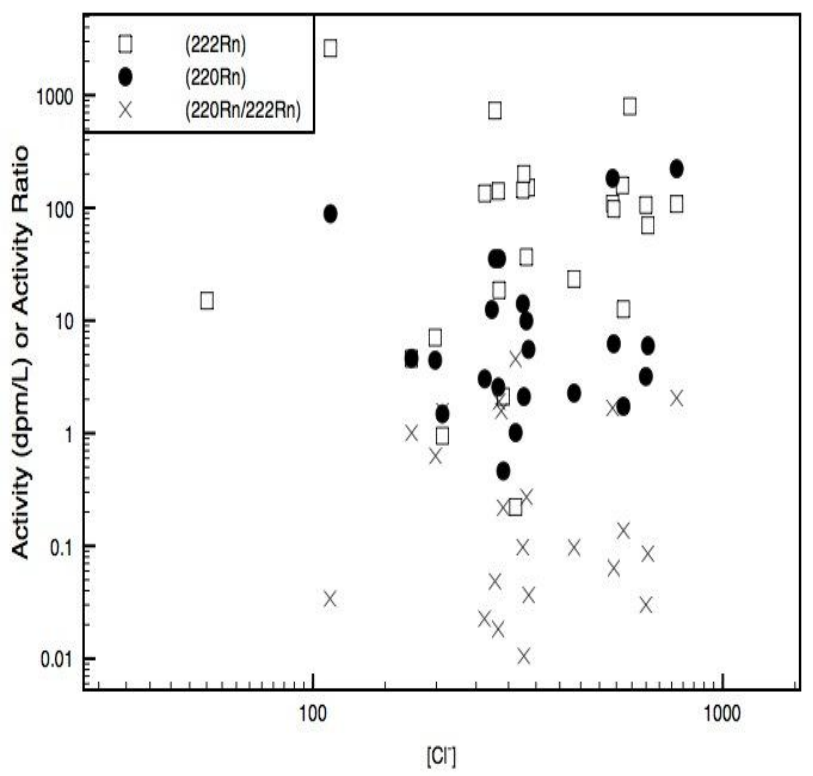

Figure 7. Thoron, radon, and $\left({ }^{220} \mathrm{Rn} /{ }^{222} \mathrm{Rn}\right)$ dissolved in spring water showed no relationship with chloride concentration. 
Radium-223 ranged from 0.00008 to 3.13 $\mathrm{dpm} / \mathrm{L},{ }^{224} \mathrm{Ra}$ ranged from 0.0053 to $21.47 \mathrm{dpm} / \mathrm{L}$, ${ }^{226} \mathrm{Ra}$ ranged from 0.037 to $1.39 \mathrm{dpm} / \mathrm{L}$, and ${ }^{228} \mathrm{Ra}$ ranged from 0.05 to $20.9 \mathrm{dpm} / \mathrm{L}$. In general, ${ }^{228} \mathrm{Ra}$ is present in the greatest activity in thermal springs in Yellowstone, followed by ${ }^{224} \mathrm{Ra},{ }^{226} \mathrm{Ra}$, and finally ${ }^{223} \mathrm{Ra}$. No radium isotope showed a significant correlation with $\mathrm{CO}_{2}$ flux, $\left({ }^{3} \mathrm{He} /{ }^{4} \mathrm{He}\right)$, or chloride, but all radium isotopes were significantly correlated with barium concentration in spring water (Figure 8).

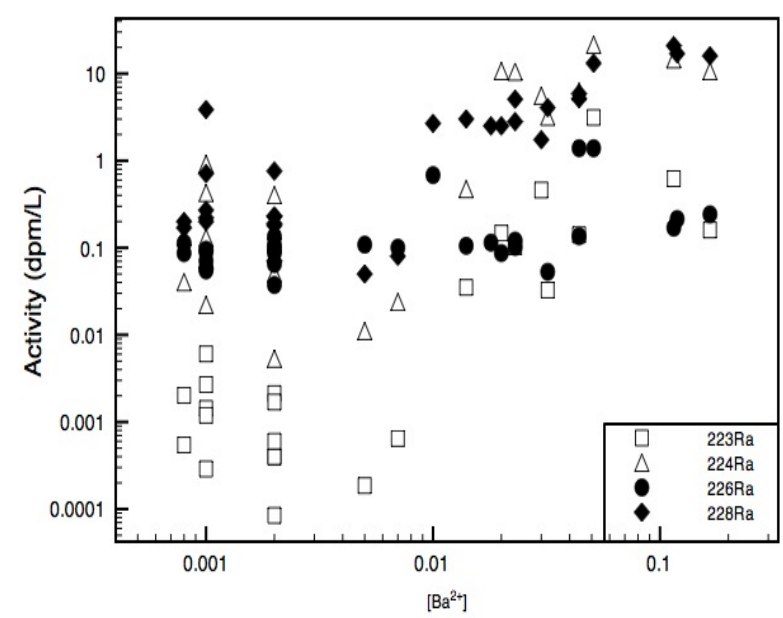

Figure 8. All radium isotopes (and total radium) showed a significant positive correlation with barium concentration in spring water.

\section{${ }^{223} \mathrm{Ra}$ and ${ }^{224} \mathrm{Ra}$}

$\left({ }^{224} \mathrm{Ra} /{ }^{223} \mathrm{Ra}\right)$ ranged from 6.86 to 298.47 . $\left({ }^{224} \mathrm{Ra} /{ }^{223} \mathrm{Ra}\right)$ showed a weak inverse correlation with $\mathrm{CO}_{2}$ flux (not statistically significant, Figure 9A). This correlation was strong for the neutral-chloride springs of the Lower Geyser Basin and Rabbit Creek Hot Springs, but the other springs showed no relationship between $\left({ }^{224} \mathrm{Ra} /{ }^{223} \mathrm{Ra}\right)$ and $\mathrm{CO}_{2}$ flux. $\left({ }^{224} \mathrm{Ra} /{ }^{223} \mathrm{Ra}\right)$ showed no relationship with $\left[\mathrm{Cl}^{-}\right]$or $\left({ }^{3} \mathrm{He} /{ }^{4} \mathrm{He}\right)$ (Figures 10A, 11).

\section{${ }^{224} \mathrm{Ra}$ and ${ }^{228} \mathrm{Ra}$}

$\left({ }^{224} \mathrm{Ra} /{ }^{228} \mathrm{Ra}\right)$ ranged from 0.076 to 4.26 . $\left({ }^{224} \mathrm{Ra} /{ }^{228} \mathrm{Ra}\right)$ was often greater than 1 for the springs from Norris Geyser Basin and Mammoth Hot Springs (mean $=1.60)$, but was usually less than 1 for the Lower Geyser Basin and Rabbit Creek Hot Springs $($ mean $=0.37) . \quad\left({ }^{224} \mathrm{Ra} /{ }^{228} \mathrm{Ra}\right)$ showed no significant relationship with $\mathrm{CO}_{2}$ flux, $\left[\mathrm{Cl}^{-}\right]$, or $\left({ }^{3} \mathrm{He} /{ }^{4} \mathrm{He}\right)$ (Figures 9B, 10B, 11).

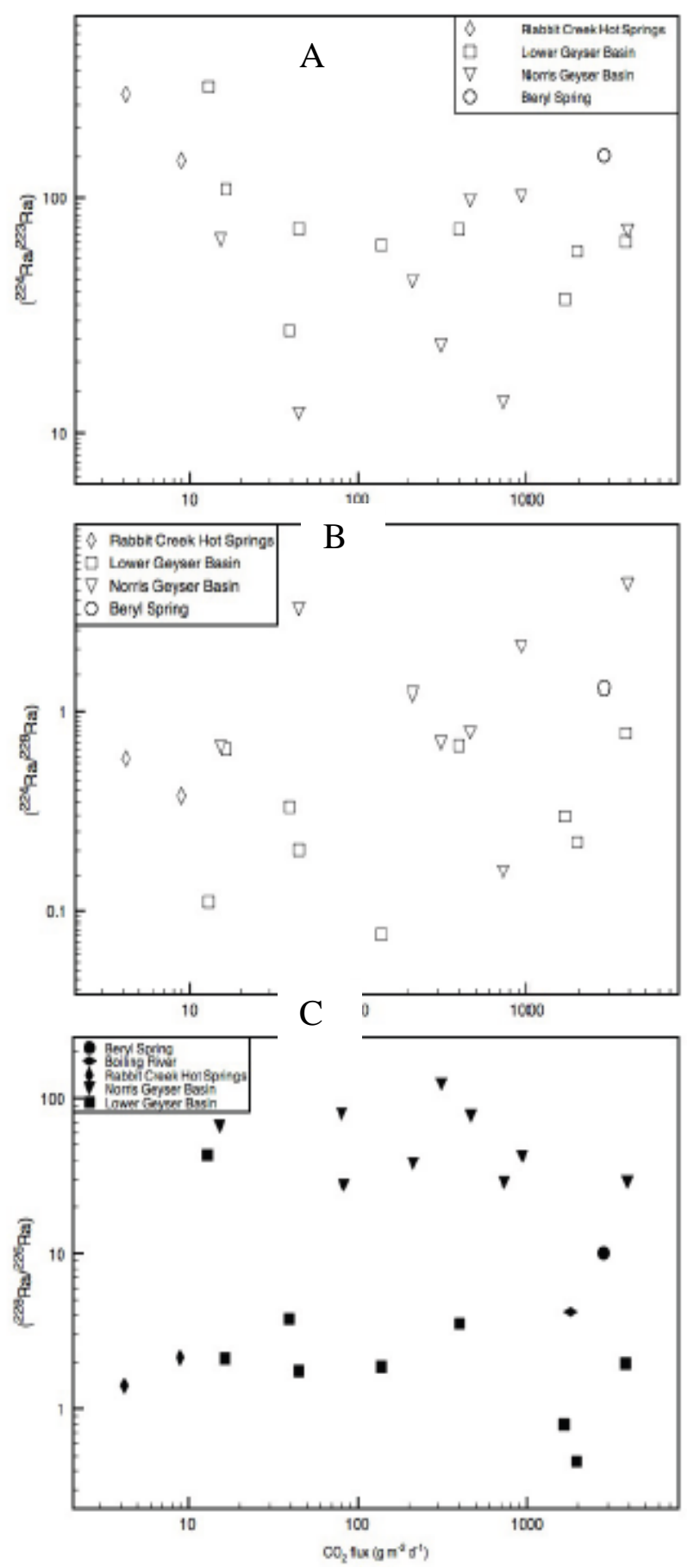

Figure 9. $\left({ }^{224} \mathrm{Ra} /{ }^{223} \mathrm{Ra}\right)$ in thermal spring water was negatively correlated with $\mathrm{CO}_{2}$ flux (A), while $\left({ }^{224} \mathrm{Ra} /{ }^{228} \mathrm{Ra}\right)$ and $\left({ }^{228} \mathrm{Ra} /{ }^{226} \mathrm{Ra}\right)$ showed no relationship with $\mathrm{CO}_{2}$ flux (B,C). The correlation between $\left({ }^{224} \mathrm{Ra} /{ }^{223} \mathrm{Ra}\right)$ and $\mathrm{CO}_{2}$ flux (A) was strong for the springs of the the Lower Geyser Basin and Rabbit Creek Hot Springs, while $\left({ }^{224} \mathrm{Ra} /{ }^{223} \mathrm{Ra}\right)$ from springs in other areas did not show a strong relationship with $\mathrm{CO}_{2}$ flux. 

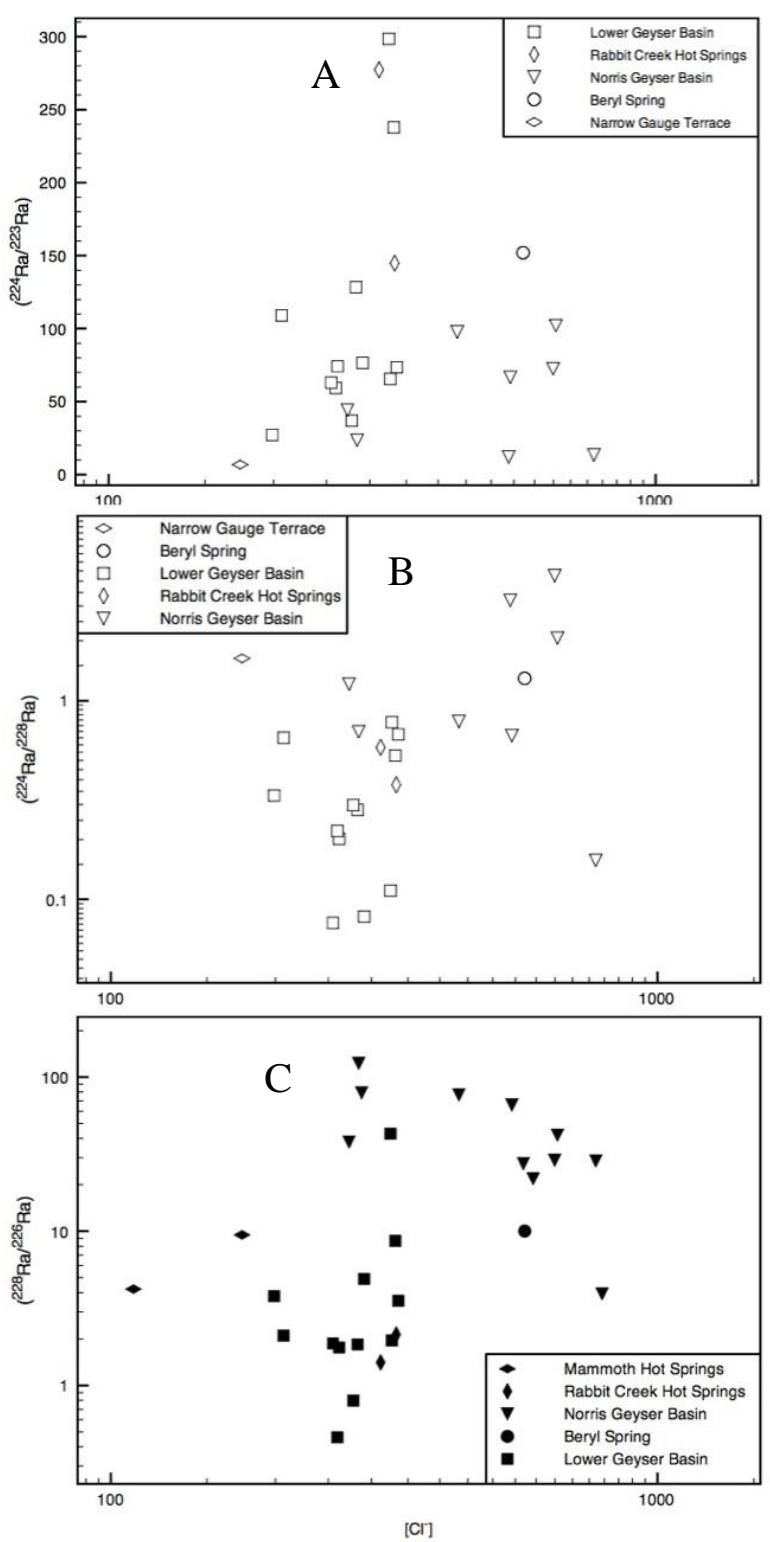

Figure 10. There were no significant relationships between $\left({ }^{224} \mathrm{Ra} /{ }^{223} \mathrm{Ra}\right)$ and $\left[\mathrm{Cl}^{-}\right](\mathrm{A})$, or $\left({ }^{224} \mathrm{Ra} /{ }^{228} \mathrm{Ra}\right)$ and $\left[\mathrm{Cl}^{-}\right](\mathrm{B})$. The acid-sulfate springs in the Norris Geyser Basin and Beryl Spring showed a negative correlation between $\left({ }^{228} \mathrm{Ra} /{ }^{226} \mathrm{Ra}\right)$ and $\left[\mathrm{Cl}^{-}\right]$, but springs from other areas showed no relationship between $\left({ }^{228} \mathrm{Ra} /{ }^{226} \mathrm{Ra}\right)$ and $\left[\mathrm{Cl}^{-}\right](\mathrm{C})$.

\section{${ }^{226}$ Ra and ${ }^{228}$ Ra}

$\left({ }^{228} \mathrm{Ra} /{ }^{226} \mathrm{Ra}\right)$ ranged from 0.46 to 122.82 . $\left({ }^{228} \mathrm{Ra} /{ }^{226} \mathrm{Ra}\right)$ was often greater than 10 for the springs from Norris Geyser Basin and Mammoth Hot Springs (mean $=39.92$ ), but was usually less than 10 for the Lower Geyser Basin and Rabbit Creek Hot Springs $($ mean $=5.58) .\left({ }^{228} \mathrm{Ra} /{ }^{226} \mathrm{Ra}\right)$ was inversely correlated with $\left[\mathrm{Cl}^{-}\right]$for the acid-sulfate springs of the Norris Geyser Basin and Beryl Spring (Pearson's Correlation, $\mathrm{r}=-0.717(9), p$ (two-tailed) $<.05$ but the other springs showed no relationship between $\left({ }^{228} \mathrm{Ra} /{ }^{226} \mathrm{Ra}\right)$ and $\left[\mathrm{Cl}^{-}\right]$. $\left({ }^{228} \mathrm{Ra} /{ }^{226} \mathrm{Ra}\right)$ showed no significant relationship with $\mathrm{CO}_{2}$ flux (Figure 9C). A small dataset (5 data points) suggests that $\left({ }^{228} \mathrm{Ra} /{ }^{226} \mathrm{Ra}\right)$ may have been inversely correlated with $\left({ }^{3} \mathrm{He} /{ }^{4} \mathrm{He}\right)$, although the sample size was too small to be statistically significant (Figure 11).

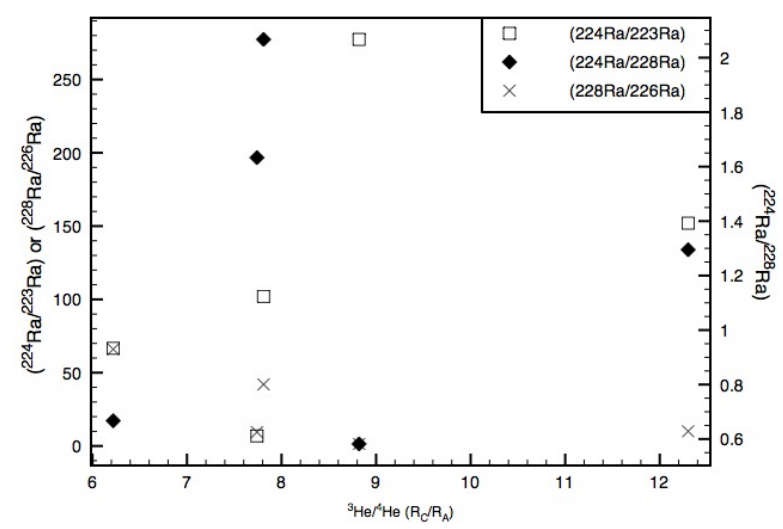

Figure 11. In a very small dataset, $\left({ }^{224} \mathrm{Ra} /{ }^{223} \mathrm{Ra}\right)$ and $\left(224 / /^{228} \mathrm{Ra}\right)$ showed no relationship to $\left({ }^{3} \mathrm{He} /{ }^{4} \mathrm{He}\right)$. $\left({ }^{228} \mathrm{Ra} /{ }^{226} \mathrm{Ra}\right)$ showed a negative correlation with $\left({ }^{3} \mathrm{He} /{ }^{4} \mathrm{He}\right)$ (not statistically significant, due to small $\mathrm{n}) .\left({ }^{3} \mathrm{He} /{ }^{4} \mathrm{He}\right)$ data from Bergfeld et al., in press.

\section{${ }^{224}$ Ra and ${ }^{222} \mathrm{Rn}$}

$\left({ }^{224} \mathrm{Ra} /{ }^{222} \mathrm{Rn}\right)$ ranged from 0.00003 to 0.78 (excluding Narrow Gauge Terrace, which had an outlier value of 4.68$). \quad\left({ }^{224} \mathrm{Ra} /{ }^{222} \mathrm{Rn}\right)$ was inversely correlated with $\left[\mathrm{Ba}^{2+} / \mathrm{Cl}^{-}\right]$((Spearman's Correlation, $\rho$ $=0.535(18), p($ two-tailed $)<.05))$.

\section{DISCUSSION}

\section{Radon and $\mathrm{CO}_{2}$}

There is a weak inverse relationship between $\left({ }^{220} \mathrm{Rn} /{ }^{222} \mathrm{Rn}\right)$ and $\mathrm{CO}_{2}$ flux from thermal features (Figure 5). This is driven by a positive link between $\left({ }^{222} \mathrm{Rn}\right)$ and $\mathrm{CO}_{2}$ flux (Figure 4F) and an apparent inverse correlation between $\left({ }^{220} \mathrm{Rn}\right)$ and $\mathrm{CO}_{2}$ flux values above $100 \mathrm{~g} \mathrm{~m}^{-2} \mathrm{~d}^{-1}$ (Figure $4 \mathrm{E}$ ). Although this correlation may be of some use in assessing the local depth of sourcing for hydrothermal fluids in different areas of Yellowstone, $\left({ }^{220} \mathrm{Rn}\right)$ and $\left({ }^{222} \mathrm{Rn}\right)$ will be strongly affected by variations in the ${ }^{238} \mathrm{U}$ and ${ }^{232} \mathrm{Th}$ content of local aquifer rocks. Simple flow velocity calculations show that if ${ }^{222} \mathrm{Rn}$ is sourced from magma $6 \mathrm{~km}$ below the surface (a likely depth from Lowenstern and Hurwitz, 2008), ${ }^{222} \mathrm{Rn}$ would need to move vertically at a velocity of 13 meters per hour to 
reach the surface before decaying to undetectable levels (5 half lives, 19.25 days). This figure is an order of magnitude higher that estimated near surface flow velocities in Yellowstone (Sturchio et al., 1993). Thus it is unlikely that any ${ }^{222} \mathrm{Rn}$ venting at the surface is sourced from magma in Yellowstone, and the utility of the radon isotope system for understanding magmatic processes is limited. This conclusion is supported by the observation that $\left({ }^{220} \mathrm{Rn}\right), \quad\left({ }^{222} \mathrm{Rn}\right)$, and $\left({ }^{220} \mathrm{Rn} /{ }^{222} \mathrm{Rn}\right)$ show no relationship with $\left({ }^{3} \mathrm{He} /{ }^{4} \mathrm{He}\right)$ isotope ratios (Figure 6). If $\left({ }^{220} \mathrm{Rn} /{ }^{222} \mathrm{Rn}\right)$ was strongly influenced by magmatic processes, one would expect an inverse correlation between between $\left({ }^{220} \mathrm{Rn} /{ }^{222} \mathrm{Rn}\right)$, which should be low in areas of intense magmatic degassing, and $\left({ }^{3} \mathrm{He} /{ }^{4} \mathrm{He}\right)$, which is higher in areas with a direct connection to the mantle.

If we accept that the inverse correlation between $\left({ }^{220} \mathrm{Rn} /{ }^{222} \mathrm{Rn}\right)$ and $\mathrm{CO}_{2}$ flux is related to the age of the hydrothermal fluid, and hence its depth of sourcing, then the relative depths of sourcing can be assessed by examination of Figure 5. Areas of relatively deep fluid sourcing plot in the lower right of the figure, areas of relatively shallow fluid sourcing plot in the upper left, and areas of intermediate source depth plot in the center. By this analysis, Beryl Spring, Boiling River, and Lone Star Geyser Basin are areas where hydrothermal fluid sourcing is relatively deep. Rabbit Creek Hot Springs is an area where hydrothermal fluid sourcing is relatively shallow. Amphitheater Springs has an intermediate source depth. The Lower and Norris Geyser Basins show a wide range of depths including some areas with a shallow signature and some with a deep signature. This analysis should be interpreted with caution due to local heterogeneity and variations in gas flow velocity. It should also be noted that none of the interpretations made above holds when examining the relationship between $\left({ }^{220} \mathrm{Rn} /{ }^{222} \mathrm{Rn}\right)$ and $\left({ }^{3} \mathrm{He} /{ }^{4} \mathrm{He}\right)$ in Figure 6B.

Generally, $\left({ }^{220} \mathrm{Rn} /{ }^{222} \mathrm{Rn}\right)$ in fumarolic gas was slightly greater $($ mean $=2.4)$ than $\left({ }^{220} \mathrm{Rn} /{ }^{222} \mathrm{Rn}\right)$ dissolved in spring water (mean $=0.69$, Figure $5 \mathrm{C}$ ). In the context of the two-component mixing model, the radon in the gas has a younger isotopic signature than the radon dissolved in water. Based on field observations of fluid discharge velocity, it is possible that the gaseous fluids discharging from fumaroles move at greater velocity than the liquid fluids discharging from springs and this accounts for the observed difference in isotopic signature. Alternatively, it is also possible that the method used for sampling the short-lived $\left({ }^{220} \mathrm{Rn}\right)$ in spring water consistently underestimates the activity due to rapid decay between the sampling point and the detector. If such a sampling bias exists, there may be no consistent difference between $\left({ }^{220} \mathrm{Rn} /{ }^{222} \mathrm{Rn}\right)$ in hydrothermal waters and gases.

\section{${ }^{224}$ Ra, ${ }^{222}$ Rn, and Recoil Supply Efficiency}

Krishnaswami et al. (1982) proposed that the activity of ${ }^{222} \mathrm{Rn}$ in groundwater could be used to estimate the recoil supply of other nuclides. Because radon is a noble gas and chemically inert, the steadystate activity (achieved after $\sim 20$ days) of radon in the aquifer will be equal to its recoil supply rate. The recoil supply rate of other nuclides can then be related to radon's supply rate:

where,

$$
\mathrm{F}_{\mathrm{i}}=\varepsilon * \mathrm{~F}_{\mathrm{r}} * \mathrm{Q}_{\mathrm{i}} / \mathrm{Q}_{\mathrm{r}}
$$

$F_{r}$ is the recoil supply rate of radon (atoms $\min ^{-1} l^{-1}$ )

$F_{i}$ is the recoil supply rate of nuclide $i$ (atoms $\min ^{-1} 1^{-1}$ )

$\mathrm{Q}_{\mathrm{r}}$ is the production rate of radon in aquifer solids (atoms $\min ^{-1} 1^{-1}$ )

$\mathrm{Q}_{\mathrm{i}}$ is the production rate of nuclide $\mathrm{i}$ in aquifer solids (atoms $\min ^{-1} 1^{-1}$ )

$\varepsilon$ is the recoil supply efficiency of nuclide i relative to radon (dimensionless)

The term $\left(\mathrm{Q}_{\mathrm{i}} / \mathrm{Q}_{\mathrm{r}}\right)$ is approximated by the $\left({ }^{228} \mathrm{Ra} /{ }^{226} \mathrm{Ra}\right)$ activity ratio in aquifer rocks. Assuming secular equilibrium in Yellowstone's aquifer rocks, this is equal to the $\left({ }^{232} \mathrm{Th} /{ }^{238} \mathrm{U}\right)$ ratio, which in Yellowstone's tuffs and rhyolites is generally greater than 1 and less than 2 (Clark and Turekian, 1990, Sturchio et al., 1993). An average value of 1.3 is used for these calculations.

Krishnaswami et al. (1982) proposed that the value of $\varepsilon$ is determined by the position of the to the nuclide within the decay chain and the adsorptive properties of its parent. Kadko and Butterfield (1998) used ${ }^{224} \mathrm{Ra}$ and ${ }^{222} \mathrm{Rn}$ to estimate recoil supply efficiencies of radium isotopes at the Juan de Fuca Ridge hydrothermal system, and found that the ${ }^{224} \mathrm{Ra}$ supply rate is $20 \%$ of what it would be expected to be based on ${ }^{222} \mathrm{Rn}$ (effectively, $\varepsilon=0.2$ ). In an aquifer, ${ }^{224} \mathrm{Ra}$ is produced by alpha decay of ${ }^{228} \mathrm{Th}\left(\mathrm{T}_{1 / 2}=1.91\right.$ $\mathrm{yr})$, which is insoluble under most conditions. Assuming there is little ${ }^{228} \mathrm{Th}$ in solution, the ${ }^{224} \mathrm{Ra}$ activity in solution is likely to be equal to its recoil supply rate.

Activities of ${ }^{222} \mathrm{Rn}$ and ${ }^{224} \mathrm{Ra}$ in hot spring water from Yellowstone National Park do not show a positive correlation as would be expected if $\varepsilon$ and $\left(\mathrm{Q}_{\mathrm{i}} / \mathrm{Q}_{\mathrm{r}}\right)$ were uniform throughout the aquifer (Figure 
12). This is most likely because there is significant variance in the $\left({ }^{228} \mathrm{Ra} /{ }^{226} \mathrm{Ra}\right)$ ratio in the aquifer solids (Sturchio et al. 1993). Nevertheless, nearly all the samples collected in this study lie above the expected curve if $\varepsilon=0.897$ as calculated by Krishnaswami et al. (1982) for Connecticut groundwater. The average $\left({ }^{224} \mathrm{Ra} /{ }^{222} \mathrm{Rn}\right)$ ratio for all samples collected is 0.39 , implying that $\varepsilon=0.3$. However, one value of the $\left({ }^{224} \mathrm{Ra} /{ }^{22} \mathrm{Rn}\right)$ ratio from Narrow Gauge Terrace is anomalously large $(5.5$, all other values $<1.07)$. This is probably because the spring geometry at Narrow Gauge makes it impossible to sample the vent directly. A side pool was sampled that had likely degassed radon to the atmosphere while retaining its radium. Excluding this value from the average gives $\left({ }^{224} \mathrm{Ra} /{ }^{222} \mathrm{Rn}\right)=0.1226$, which gives $\varepsilon=0.09$. A range of $\varepsilon$ values from 0.3 to 0.09 is comparable to the value of 0.2 observed by Kadko and Butterfield (1998) at the Juan de Fuca Ridge.

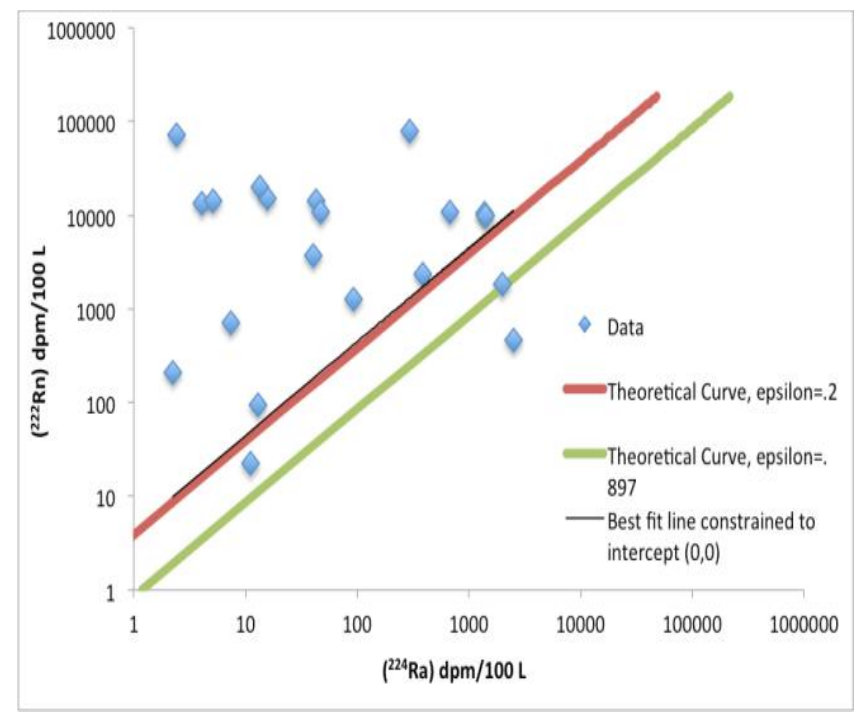

Figure 12. Activities of ${ }^{222} \mathrm{Rn}$ and ${ }^{224} \mathrm{Ra}$ in hot spring water. Curves are plotted showing the expected relationship between ${ }^{222} \mathrm{Rn}$ recoil supply and ${ }^{224} \mathrm{Ra}$ recoil supply assuming a $\left({ }^{228} \mathrm{Ra} /{ }^{226} \mathrm{Ra}\right)$ value of 1.3 in the aquifer rocks. The lower curve is what would be expected if $\varepsilon=0.897$ as calculated by Krishnaswami et al. (1982). The higher curve is if $\varepsilon=0.2$ as found by Kadko and Butterfield (1998). $\varepsilon=2$ produces a line in better agreement with the best fit line, which is constrained to intercept the origin.

\section{$\downarrow$ CONCLUSIONS}

The relationship between $\left({ }^{220} \mathrm{Rn} /{ }^{222} \mathrm{Rn}\right)$ and $\mathrm{CO} 2$ flux is statistically significant, but it is not strong, nor is it confirmed by any other isotope system, nor any other proxy of magmatic components, such as chloride concentration or $\left({ }^{3} \mathrm{He} /{ }^{4} \mathrm{He}\right)$ ratios. Our interpretation is that gas transport time from magma to surface in Yellowstone is greater than 20 days, such that no $\left({ }^{222} \mathrm{Rn}\right)$ or $\left({ }^{220} \mathrm{Rn}\right)$ venting to the surface is sourced directly from magma.

Gas vents, on average, are enriched in short lived $\left({ }^{220} \mathrm{Rn}\right)$ relative to spring water which is more enriched in the longer lived $\left({ }^{222} \mathrm{Rn}\right)$. This could possibly be due to greater fluid discharge velocity in gas vents relative to springs.

Neutral chloride springs in the Lower Geyser Basin and Rabbit Creek Hot Springs have isotopically old water that is enriched in the longer lived isotopes of radium, compared the to springs of Norris Geyser Basin and Mammoth Hot Springs which show relative enrichment of the shorter-lived radium isotopes.

Mineral (barite, in particular) precipitation may be a strong control on the amount of radium in solution in any given spring, as evidenced by strong correlations between the activity of all radium isotopes and $[\mathrm{Ba} 2+]$ in spring water, and a correlation between $\left({ }^{224} \mathrm{Ra} /{ }^{222} \mathrm{Rn}\right)$ and $\left[\mathrm{Ba}^{2+} / \mathrm{Cl}^{-}\right]$. This removal of ${ }^{224} \mathrm{Ra}$ by precipitation (or other process such as sorption) results in a very low recoil supply efficiency for ${ }^{224} \mathrm{Ra}$ (and presumably all other radium isotopes) relative to ${ }^{222} \mathrm{Rn}$. A reasonable efficiency is about $20 \%$.

\section{$\uparrow \quad$ ACKNOWLEDGEMENTS}

In addition to support from the UW-NPS Research Station, this project has received key funding from the Department of Geology at the University of Wyoming, and the United States Department of Energy. The authors gratefully thank Kirk Nordstrom and Blaine McCleskey of the USGS, and the rest of their research group, for providing assistance and guidance in the field and their analysis of water samples. The study was aided by insightful guidance and input from Jacob Lowenstern of the USGS, Hank Heasler and Cheryl Jaworowski of NPS, and Matt Charette of Woods Hole Oceanographic Institution. We also wish to thank Hank Heasler, Cheryl Jaworowski, and Christie Hendrix for their help and cooperation in the use of NPS facilities, and Paul Henderson of WHOI for his work in gamma counting samples for this study. The authors are very grateful to all those individuals who assisted with fieldwork, including Allison Pluda, Tim Matthews, Chris Waters, Virginia Marcon, and Salvo Giammanco. 


\section{LiTERATURE CiTED}

Ball JW, McCleskey RB, Nordstrom DK. 2010, Water-chemistry data for selected springs, geysers, and streams in Yellowstone National Park, Wyoming, 2006-2008: U.S. Geological Survey Open-File Report 20101192, 109p. [http://pubs.usgs.gov/of/2010/1192/]

Barringer JL, Johnsson, PA. 1996. Theoretical considerations and a simple method for measuring alkalinity and acidity in low-pH waters by Gran titration. U.S. Geological Survey Water-Resources Investigations Report 89-4029, p. 36.

Bergfeld D, Lowenstern JB, Hunt AG, Shanks III WCP, Evans WC. in press. Gas and Isotope Chemistry of Thermal Features from Yellowstone National Park. U.S. Geological Survey Scientific Investigations Report 2010-XXXX.

Chiodini G, Cioni R, Guidi M, Raco B, Marini L. 1998. Soil $\mathrm{CO}_{2}$ flux measurements in volcanic and geothermal areas, Applied Geochemistry, v. 13, p. 135-148.

Christiansen R. 2001. The Geology of Yellowstone National Park: The Quaternary and Pliocene Yellowstone Plateau Volcanic Field of Wyoming, Idaho, and Montana, USGS Professional Paper 729-G, 145p.

Clark JF, Turekian KK. 1990. Time scale of hydrothermal water-rock reactions in Yellowstone National Park based on radium isotopes and radon. Journal of Volcanology and Geothermal Research, v. 40, p. 169180.

Dimova N, Burnett WC, Horwitz EP, Lane-Smith D, 2007. Automated measurement of ${ }^{224} \mathrm{Ra}$ and ${ }^{226} \mathrm{Ra}$ in water. Applied Radiation and Isotopes, v. 65, p. 428-434.

Fournier RO. 1989. Geochemistry and dynamics of the Yellowstone National Park hydrothermal system. Annual Reviews of Earth and Planetary Science, v. 17, p. 13-53.

Jaworowski C, Case JC, Larsen L, Reimer GM, Szarzi SL, Been JM, Crysdale B, Brown MA, Jacobs M, Martineau R, Wood J. 1996. Reconnaissance of radon in soil-gas and water in Yellowstone National Park.
In: Wyoming Geological Association 47th Guidebook, pp. 324-358.

Kadko D, Butterfield DA. 1998. The relationship of hydrothermal fluid composition and crustal residence time to maturity of vent fields on the Juan de Fuca Ridge, Geochimica et Cosmochimica Acta, v. 62, p. 1521-1533.

Kim G, Burnett WC, Dulaivoa H, Swarzenski PW, Moore WS. 2001. Measurement of 224Ra and ${ }^{226} \mathrm{Ra}$ activities in natural waters using a radon-in-air monitor. Environmental Science and Technology, v. 35, p. 46804683.

Krishnaswami S, Graustein WC, Turekian KK, Dowd JF. 1982. Radium, Thorium and Radioactive Lead Isotopes in Groundwaters: Application to the in Situ Determination of AdsorptionDesorption Rate Constants and Retardation Factors, Water Resources Research, v. 18, p. 1633-1675.

Lowenstern JB, Hurwitz S. 2008. Monitoring a supervolcano in repose: heat and volatile flux at the Yellowstone Caldera. Elements, v. 4, p. 35-40.

Moore WS, Arnold R. 1996. Measurement of ${ }^{223} \mathrm{Ra}$ and ${ }^{224} \mathrm{Ra}$ in coastal waters using a delayed coincidence counter. Journal of Geophysical Research, v. 101, p. 1321-1329.

Moore WS. 2008. Fifteen years experience in measuring ${ }^{224} \mathrm{Ra}$ and ${ }^{223} \mathrm{Ra}$ by delayedcoincidence counting. Marine Chemistry, v. 109, p. 188-197.

Sturchio NC, Bohlke JK, Binz CM. 1989. Radiumthorium disequilibrium and zeolite-water ion exchange in a Yellowstone hydrothermal environment. Geochimica et Cosmochimica Acta, v. 53, p. 1025-1034.

Sturchio NC, Bohlke JK, Markun FJ. 1993. Radium isotope geochemistry of thermal waters, Yellowstone National Park, Wyoming, USA. Geochimica et Cosmochimica Acta, v. 57, p. 1203-1214.

Vasquez JA, Reid MR. 2002. Time scales of magma storage and differentiation of voluminous high-silica rhyolites at Yellowstone caldera, Wyoming. Contributions to Mineralogy and Petrology, v. 144, p. 274-285. 


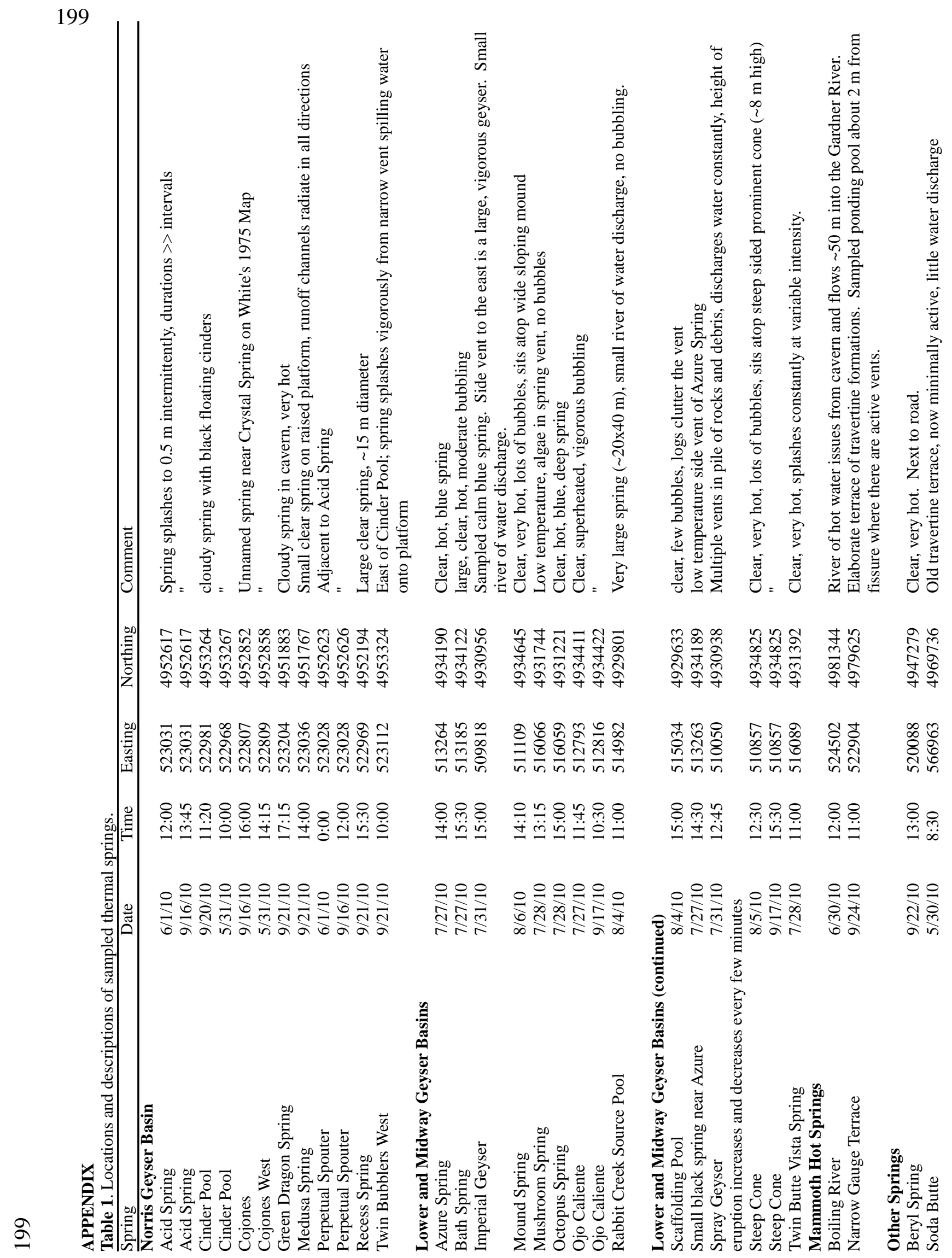


늘

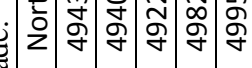

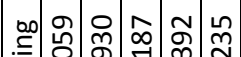
空

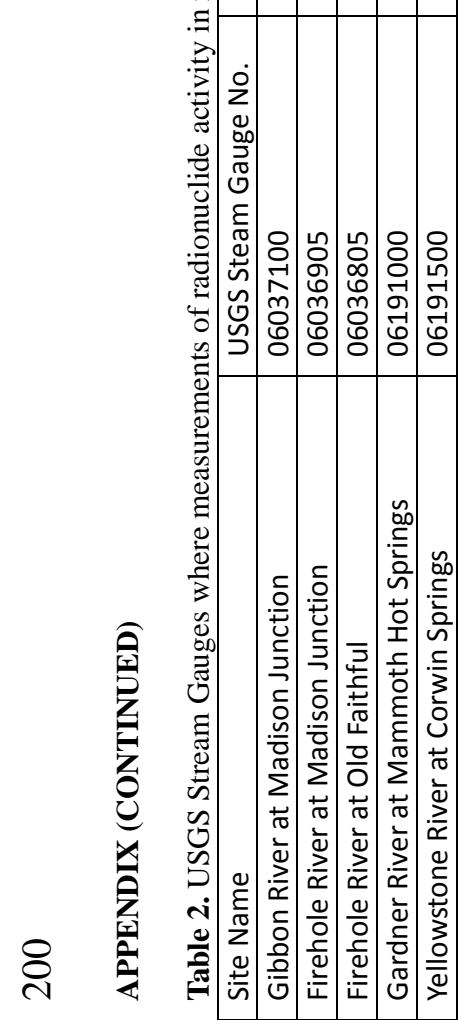

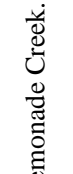

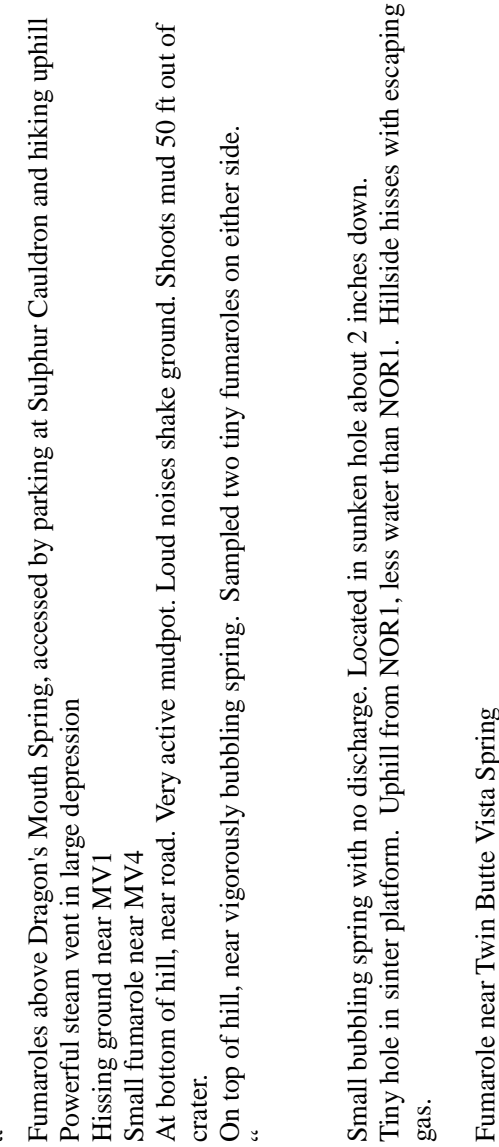

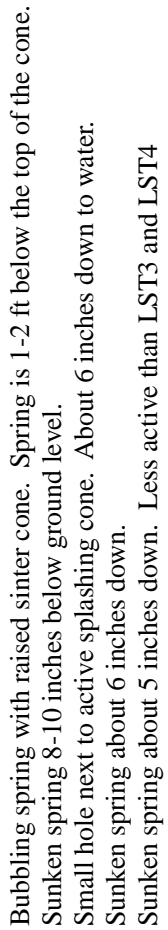

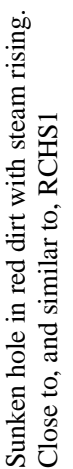

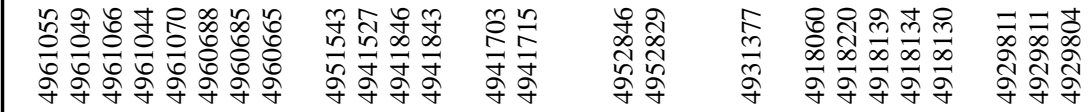

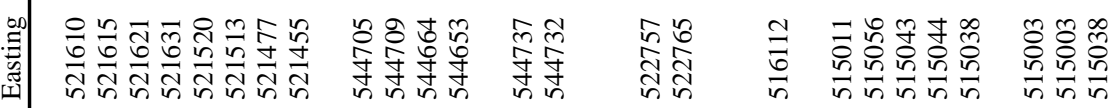

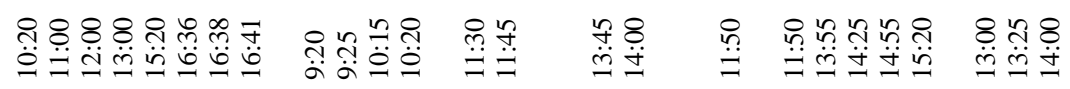

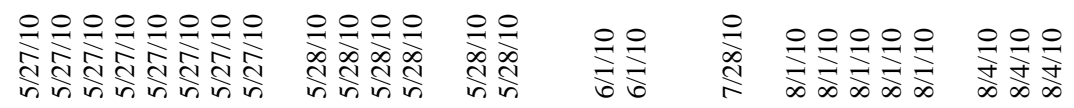




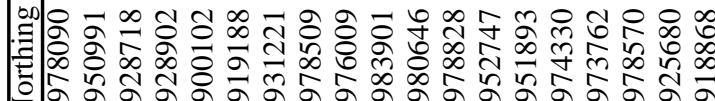

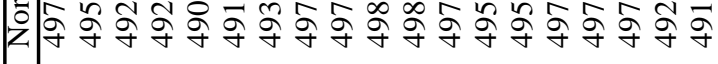

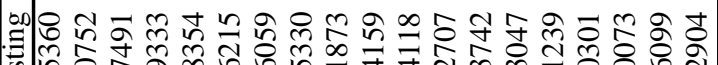

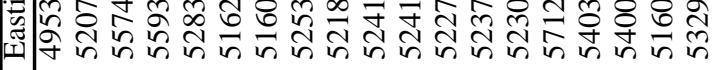

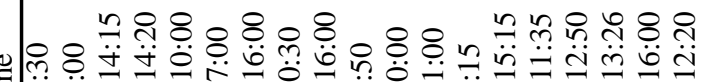

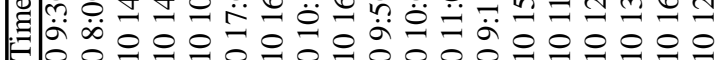

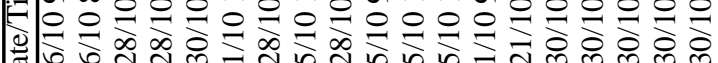

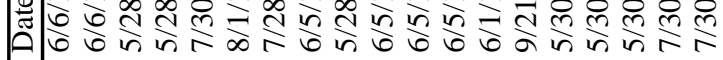

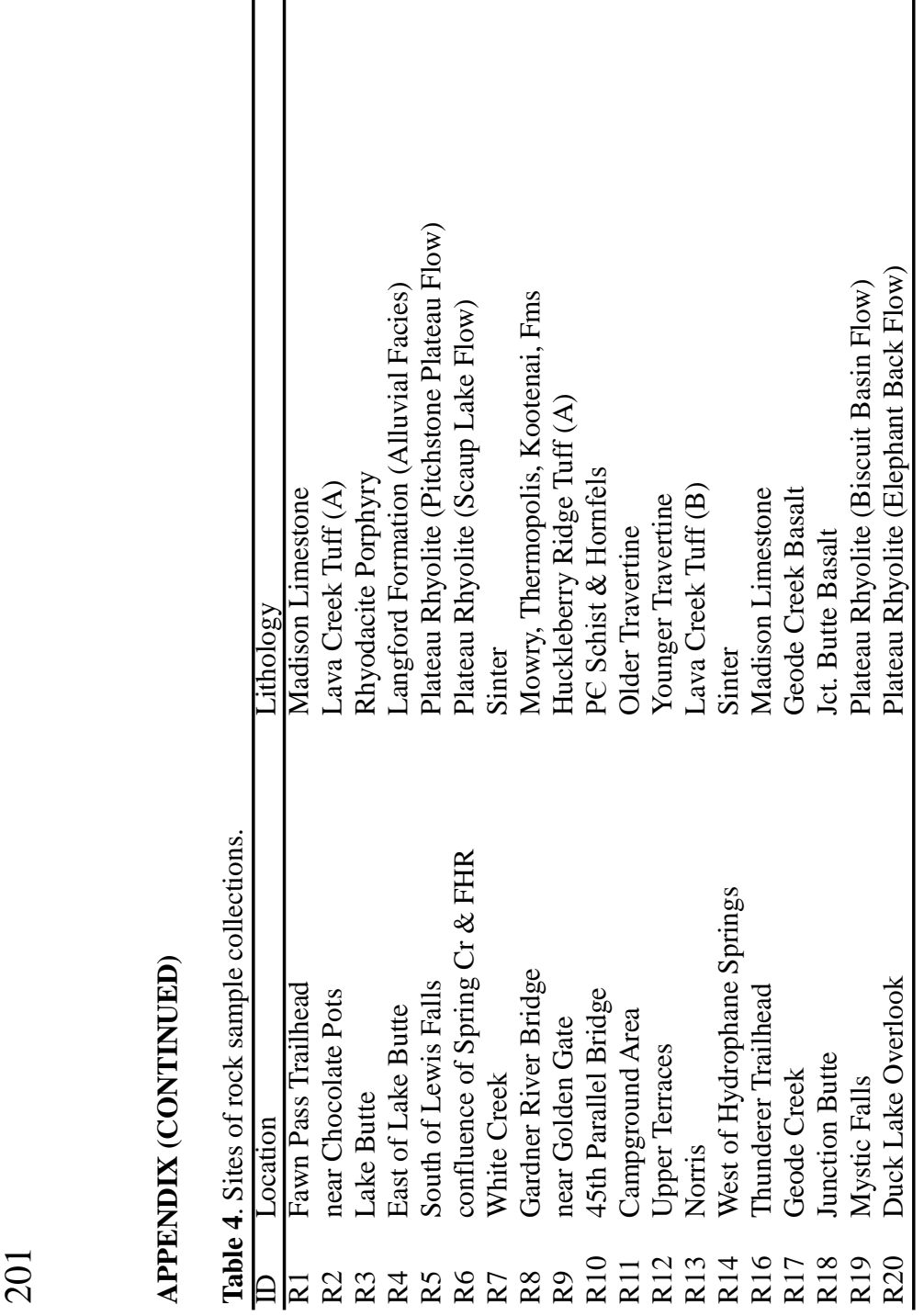




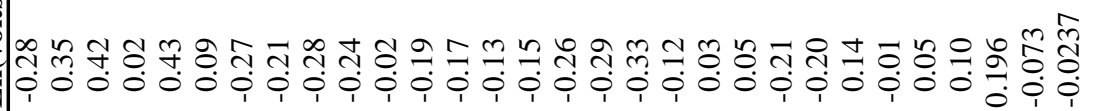

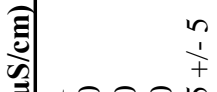

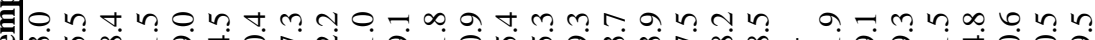

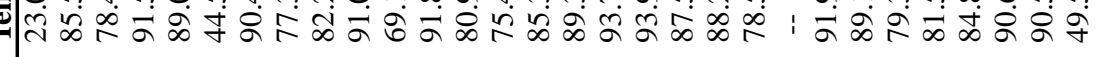

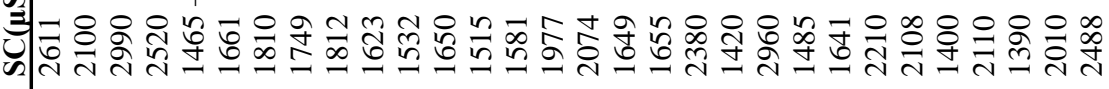

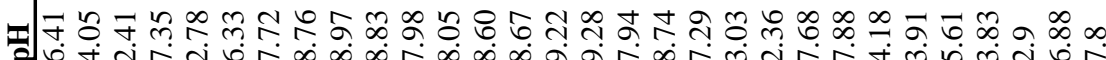

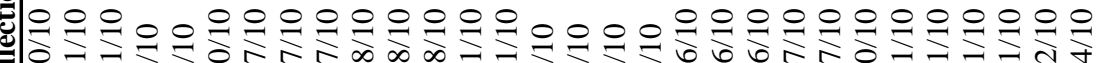

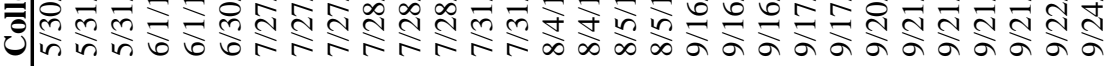




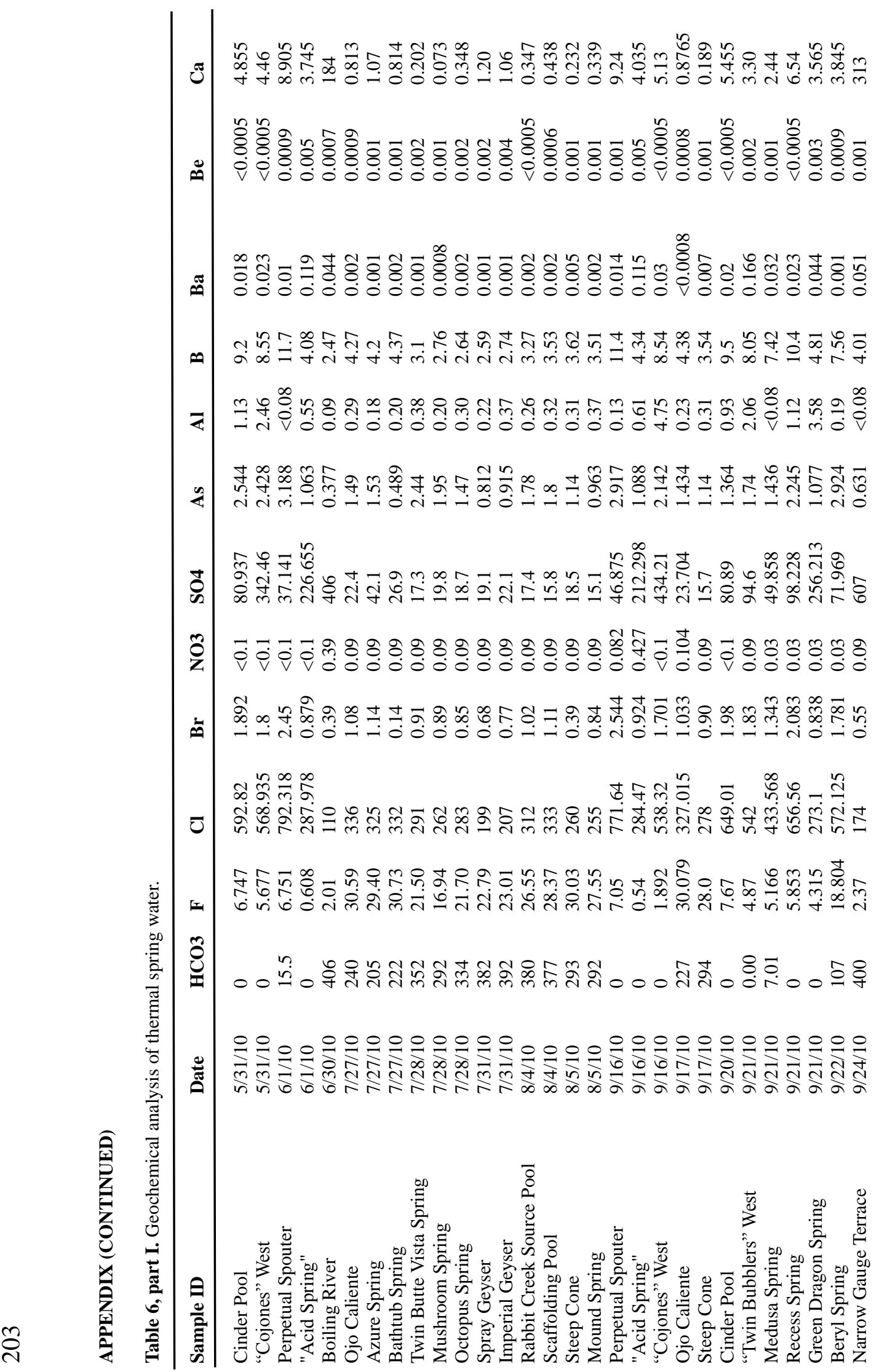




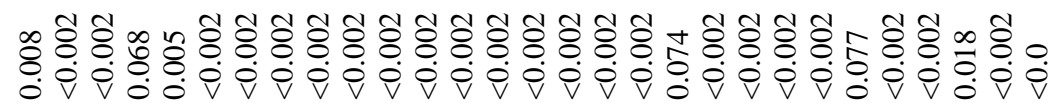

率

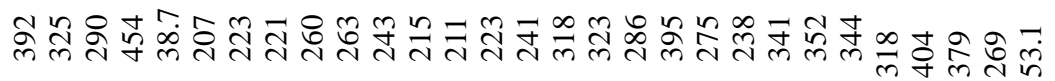

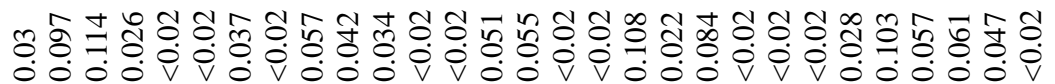

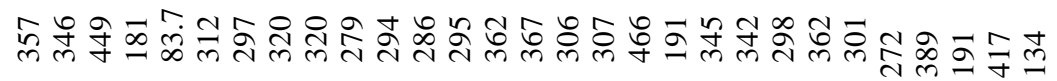

ஓ

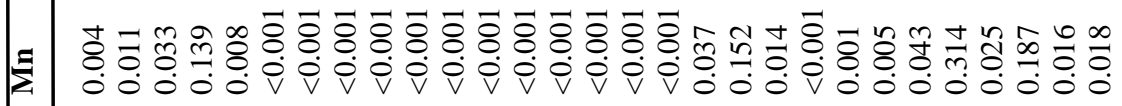

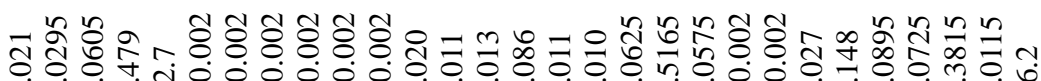

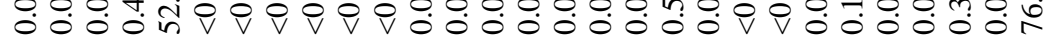

ทุ่

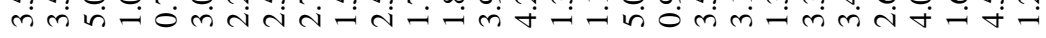

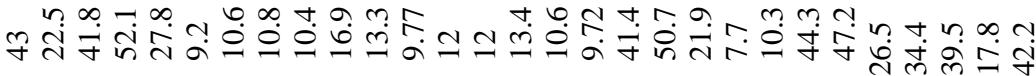

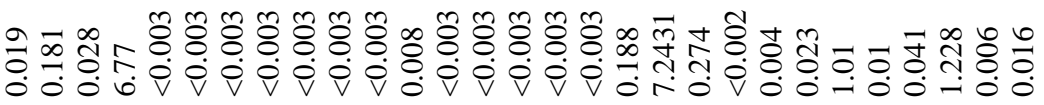

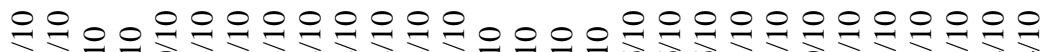

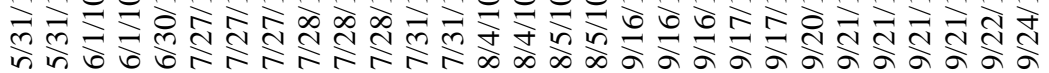

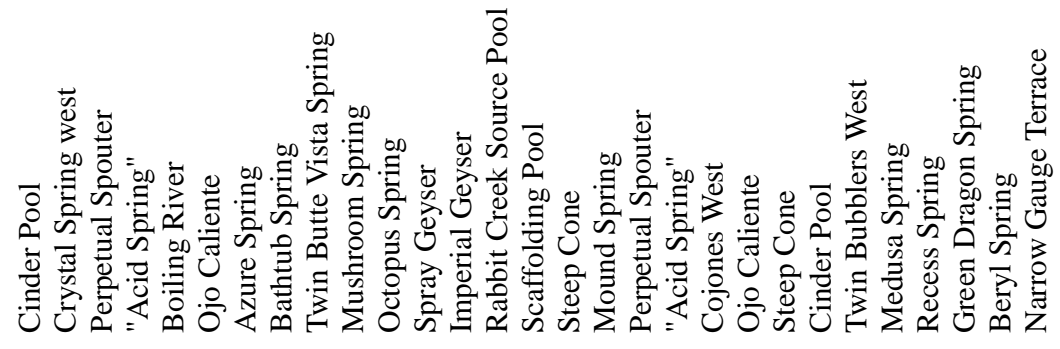




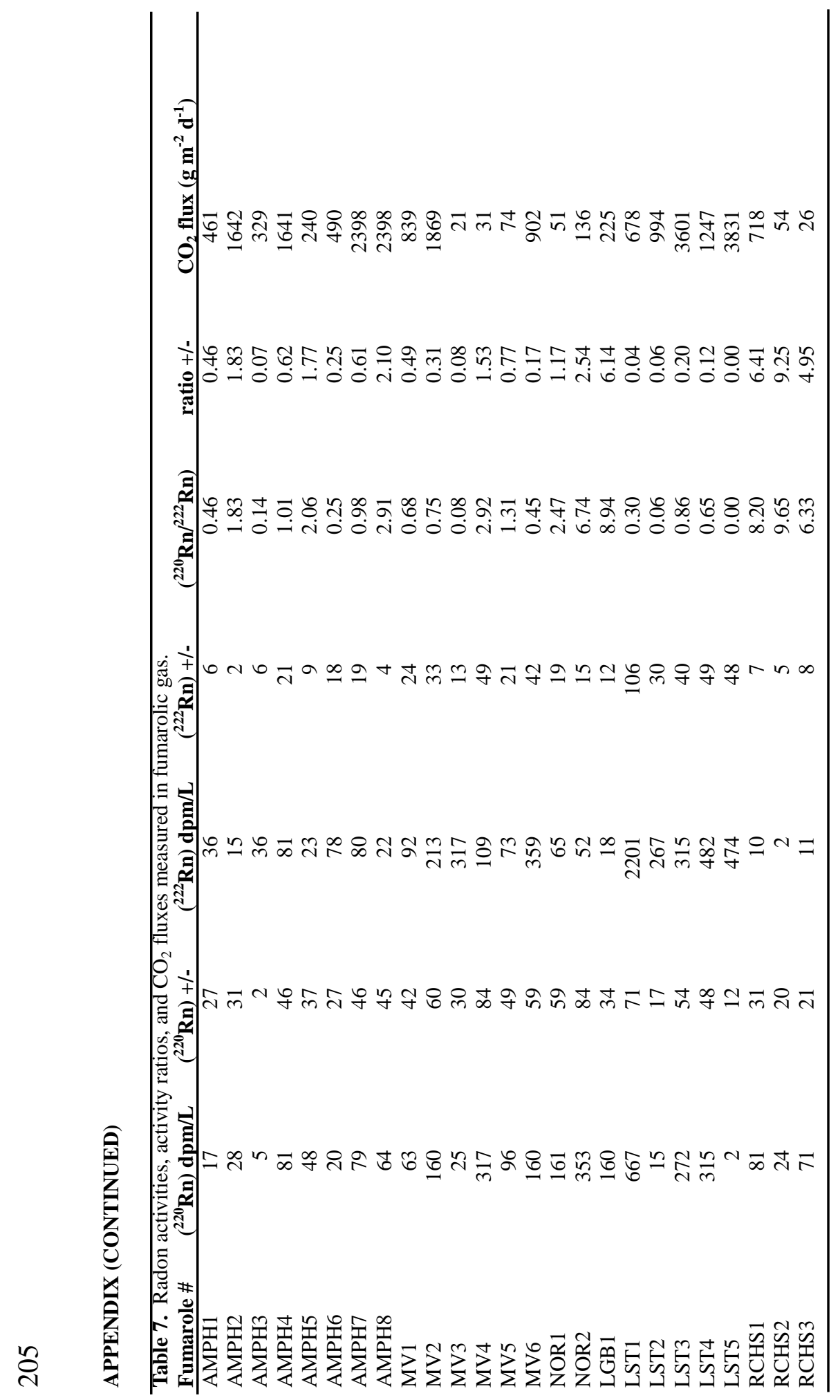




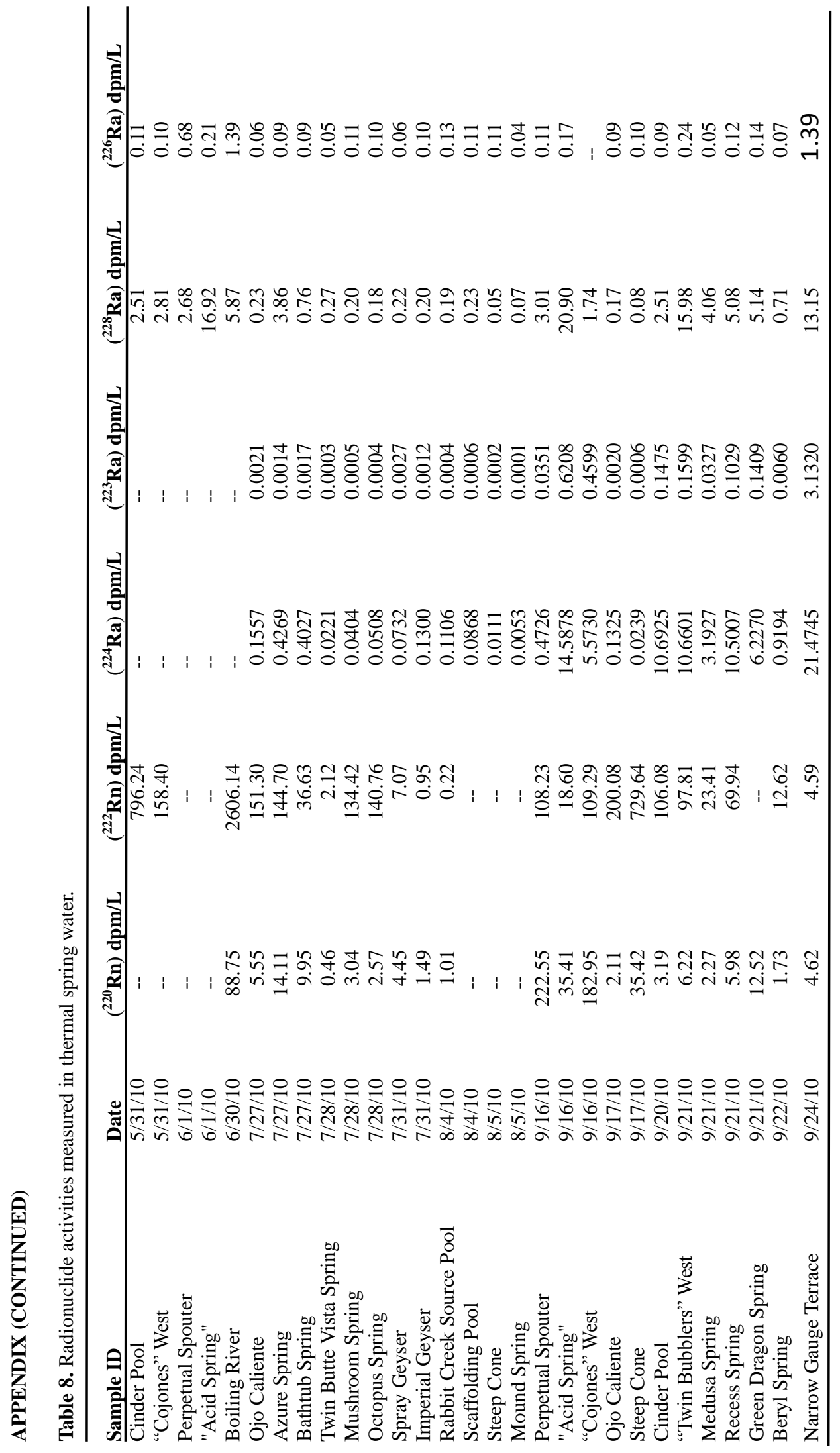




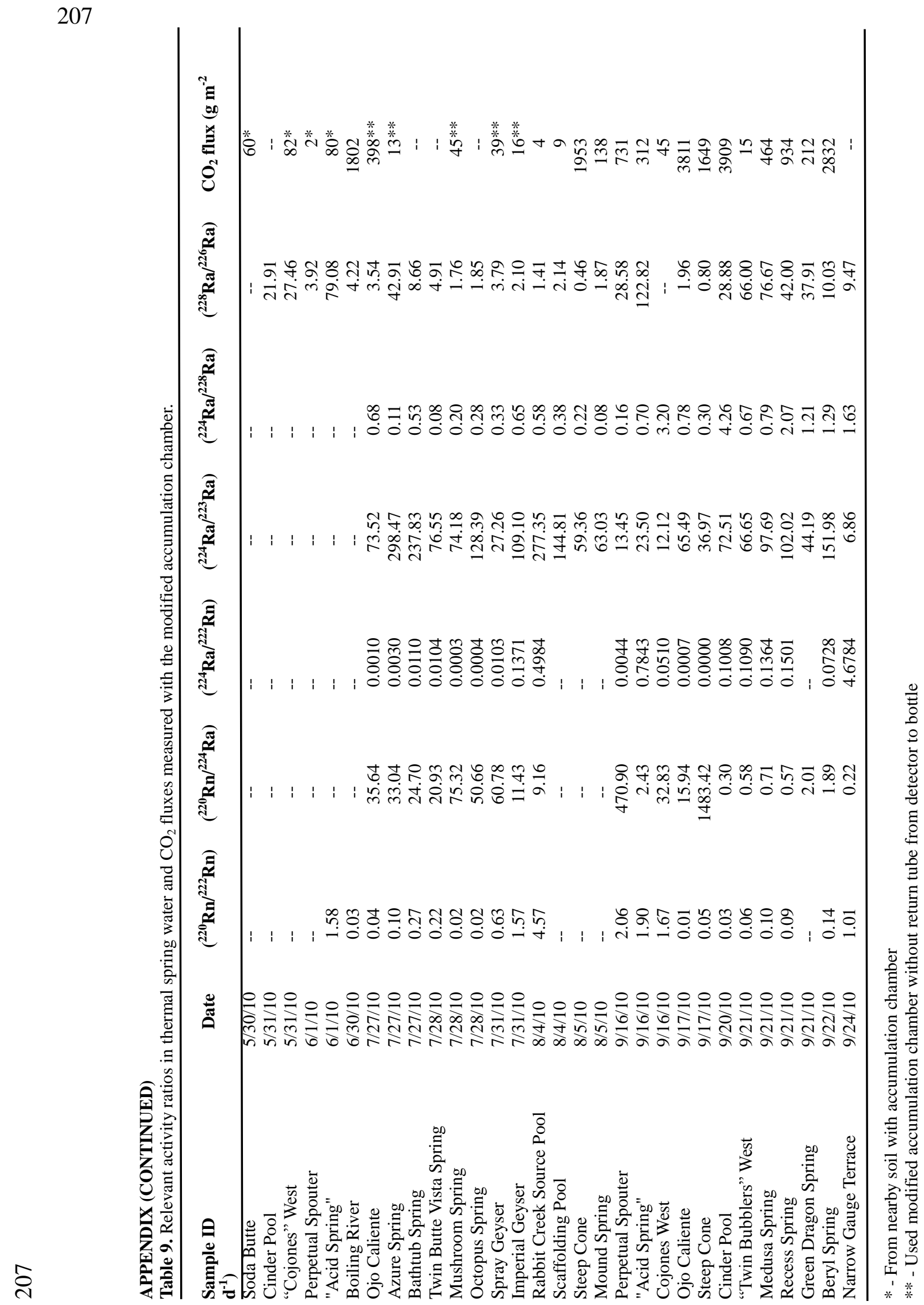

